\title{
Cultivars to face climate change effects on crops and weeds: a review
}

\author{
Nicholas E. Korres ${ }^{1}$ - Jason K. Norsworthy ${ }^{1} \cdot$ Parsa Tehranchian ${ }^{1}$. \\ Thomas K. Gitsopoulos ${ }^{2}$ • Dimitra A. Loka ${ }^{3}$ • Derrick M. Oosterhuis ${ }^{1} \cdot$ David R. Gealy $^{4}$. \\ Stephen R. Moss ${ }^{5}$ - Nilda R. Burgos ${ }^{1}$ - M. Ryan Miller ${ }^{1}$ - Matheus Palhano ${ }^{1}$
}

Accepted: 4 January 2016 /Published online: 18 February 2016

(C) INRA and Springer-Verlag France 2016

\begin{abstract}
Climate change is caused by the release of greenhouse gases in the atmosphere. Climate change will impact many activities, but its effects on agricultural production could be acute. Estimates of annual damages in agriculture due to temperature increase or extended periods of drought will be more costly than damages in other activities. Yield losses are caused both by direct effects of climate change on crops and by indirect effects such as increased inputs in crop production for weed control. One possible solution to counteract the effects of climate change is to seek crop cultivars that are adapted to highly variable, extreme climatic conditions and pest changes. Here we review the effects of climate change on crop cultivars and weeds. Biomass increase will augment marketable yield by 8 $70 \%$ for C3 cereals, by $20-144 \%$ for cash and vegetable crops, and by $6-35 \%$ for flowers. Such positive effects could however be reduced by decreasing water and nutrient availability. Rising temperature will decrease yields of
\end{abstract}

Nicholas E. Korres

nkorres@yahoo.co.uk

1 Department of Crop, Soil, and Environmental Sciences, University of Arkansas, Fayetteville, AR 72704, USA

2 Hellenic Agricultural Organization-Demeter, Institute of Plant Breeding and Phytogenetic Resources, P.O. Box 60324, Thermi, Thessaloniki, Greece

3 Institute of Biological, Environmental and Rural Sciences, Aberystwyth University, Ceredigion SY23 3EB, UK

4 USDA-ARS, Dale Bumpers National Rice Research Center, Stuttgart, AR 72160, USA

5 Rothamsted Research, West Common, Harpenden, Hertfordshire AL5 2JQ, UK temperature-sensitive crops such as maize, soybean, wheat, and cotton or specialty crops such as almonds, grapes, berries, citrus, or stone fruits. Rice, which is expected to yield better under increased $\mathrm{CO}_{2}$, will suffer serious yield losses under high temperatures. Drought stress should decrease the production of tomato, soybean, maize, and cotton. Nevertheless, reviews on $\mathrm{C} 4$ photosynthesis response to water stress in interaction with $\mathrm{CO}_{2}$ concentration reveal that elevated $\mathrm{CO}_{2}$ concentration lessens the deleterious effect of drought on plant productivity. $\mathrm{C} 3$ weeds respond more strongly than $\mathrm{C} 4$ types to $\mathrm{CO}_{2}$ increases through biomass and leaf area increases. The positive response of $\mathrm{C} 3$ crops to elevated $\mathrm{CO}_{2}$ may make $\mathrm{C} 4$ weeds less competitive for $\mathrm{C} 3$ crops, whereas $\mathrm{C} 3$ weeds in $\mathrm{C} 4$ or $\mathrm{C} 3$ crops could become a problem, particularly in tropical regions. Temperature increases will mainly affect the distribution of weeds, particularly $\mathrm{C} 4$ type, by expanding their geographical range. This will enhance further yield losses and will affect weed management systems negatively. In addition, the expansion of invasive weed species such as itchgrass, cogongrass, and witchweed facilitated by temperature increases will increase the cost for their control. Under water or nutrient shortage scenarios, an r-strategist with characteristics in the order S-C-R, such as Palmer amaranth, large crabgrass, johnsongrass, and spurges, will most probably prevail. Selection of cultivars that secure high yields under climate change but also by competing weeds is of major importance. Traits related with (a) increased root/shoot ratio, (b) vernalization periods, (c) maturity, (d) regulation of node formation and/or internode distance, (e) harvest index variations, and (f) allelopathy merit further investigation. The cumulative effects of selecting a suitable stress tolerator-competitor cultivar will be reflected in reductions of environmental pollution, lower production costs, and sustainable food production. 
Keywords Allelopathy - Stress tolerance - Climate change . Carbon dioxide $\cdot$ Drought $\cdot$ Temperature $\cdot$ Weed competition . Competitive ability $\cdot$ Cultivar selection $\cdot$ Integrated weed management

\section{Contents}

1 Introduction

2 Effects of climate change on crops

2.1 Effects of elevated $\mathrm{CO}_{2}$

2.1.1 Effects of elevated $\mathrm{CO}_{2}$ on crop physiological characteristics

2.1.2. Effects of elevated $\mathrm{CO}_{2}$ on crop yields

2.2 Effects of temperature increases

2.2.1 Effects of temperature increases on crop physiological characteristics

2.2.2 Effects of temperature increases on crop yield

2.3 Effects of water deficit

2.3.1 Effects of water deficit on crop physiological characteristics

2.3.2 Effects of water deficit on crop yield

2.4 Interactive effects of climate change components

on the physiology of crop plants and yield

3 Effects of climate change on weeds

3.1 Effects of elevated $\mathrm{CO}_{2}$

3.1.1 Direct effects of elevated $\mathrm{CO}_{2}$ on weeds

3.1.2 Indirect effects of elevated $\mathrm{CO}_{2}$ on weeds

3.1.3. Effects of elevated $\mathrm{CO}_{2}$ on crop-weed interference

3.2 Effects of temperature

3.2.1 Effects of temperature on weed physiological characteristics

3.2.2 Effects of temperature on weed distribution

3.3 Effects of water deficit

3.3.1 Effects of drought on weed physiological responses

3.3.2 Weed adaptation strategies under water deficit and other unfavorable conditions

3.4 Interactive effects of climate change components on weed performance and consequences on weedcrop competition

4 Cultivar selection against weeds and traits that confer competitiveness

4.1 Cultivar phenotypic characteristics and weed suppression

4.2 Implications for allelopathic properties

5 Traits for developing an ideotype S-C cultivar

5.1 Cultivars with deep root system

5.2 Harvest index and dry mater components

5.3 Late-maturing cultivars

5.4 Nutrient uptake and utilization

5.5 Heat tolerance-improvements and expectations

5.6 A synthesis
6 Conclusions

References

\section{Introduction}

Climate change refers to long-term changes in the state of the climate (IPCC 2014). These changes are identifiable, i.e., the mean or the variability of climate change components such as the increase of temperature or elevated atmospheric $\mathrm{CO}_{2}$ levels can be assessed by the application of appropriate analytical and statistical methods (IPCC 2014). The release of greenhouse gases (carbon dioxide, methane, nitrous oxide) due to various anthropogenic activities is very likely to be one of the major causes of recent climatic change (Glover et al. 2008). Plausible climate change scenarios include higher atmospheric $\mathrm{CO}_{2}$ concentrations, higher temperatures, and changes in precipitation (Adams et al. 1998; Trenberth et al. 2007).

Climate change will impact many aspects of the human and natural world (IPCC 2007), but its effects on agricultural production could be of particular significance (Cline 1992). According to Cline (1992), estimates of annual damages in agriculture due to temperature increase, for example, will be more costly to the US economy compared to those in other sectors and activities such as forestry, electricity, water availability or water pollution, air pollution, human mortality and morbidity, leisure activities, migration, human amenities, and urban infrastructure. The multifaceted climate alterations necessitate the adaptation of crop plants to tolerate increased heat, extended drought periods (Fig. 1a) (Gala Bijl and Fisher 2011), or increased flooding in tropical places. Additionally, the expected changes in the distribution, abundance, and severity of pests and weeds (Bazzaz and Carlson 1984; Ziska and Runion 2007; Ziska 2014a, b) will affect cropping systems and pest control methods (Anonymous 2008). Although climate changes compel agriculture to be adequately productive (Tokatlidis 2013), its effects on agricultural production can be positive in some agricultural systems and regions and negative in others (Gregory et al. 2005; Obirih-Opareh and Adwoa Onumah 2014).

To counteract the effects of climate change, various adaptation strategies have been suggested. These, according to IPCC (2014), are the processes of adjustment to actual or expected climatic changes and its effects. In agricultural production systems, adaptations seek to lessen or avoid damages caused by climate changes or exploit beneficial opportunities (IPCC 2001; Adger et al. 2002). Farmers, throughout history, responded to changes in the environment by adopting new crop cultivars and by adjusting their cultural practices (Gala Bijl and Fisher 2011). At the farm level, these adaptations include alterations in planting and harvest dates, changes in cropping sequence, better management of water for irrigation, optimized use of fertilizers, and adoption of various tillage 
Fig. 1 A water-stressed cotton field (a) (with permission from D. M. Oosterhuis) and heavily infested cotton field by Palmer amaranth (b) (with permission from J. K. Norsworthy)
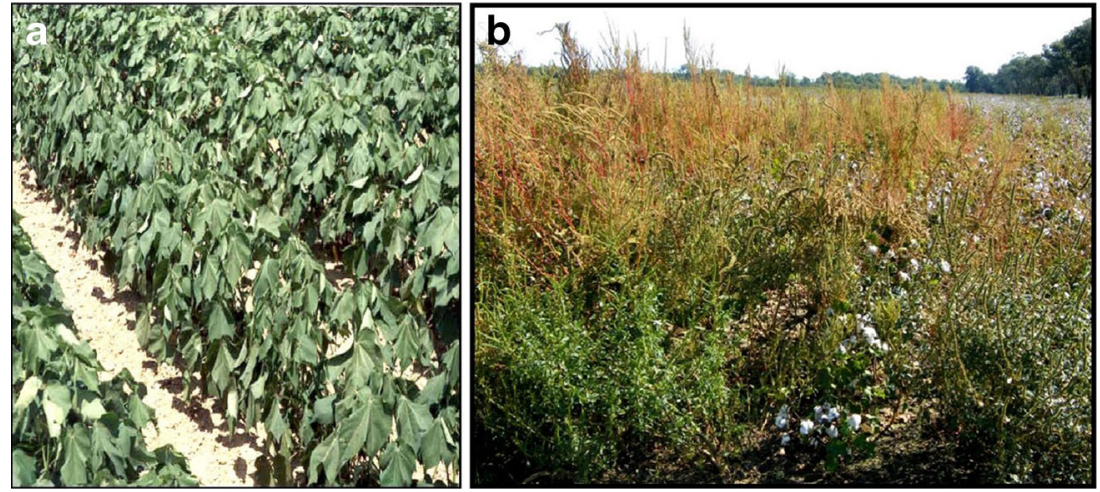

practices (Adams et al. 1998). In addition, studies in Australia showed that crop responses to climate change are strongly cultivar-dependent (Wang et al. 1992). Asfaw and Lipper (2011) predicted that the farmers' primary response to climate change would be to seek and crop cultivars that are most adapted to highly variable, extreme climatic conditions and pest changes brought forth by global warming.

Weed interference, in addition to climate change, enhances the risk for further crop yield losses. Despite the advanced technological achievements for weed control, crop yields are suffering great losses due to weed competition (Fig. 1b). Overall, weeds caused the greatest potential loss (34 \%), with animal pests and diseases being, usually, less important (losses of 18 and $16 \%$ respectively) (Oerke 2006). Competitiveness, adaptation, and stress tolerance are the characteristics by which weed species secure their survival in a variety of environmental conditions. Competitiveness, within the context of this paper, pertains to the ability of an organism (weed species in this case) to perform better in acquiring resources in relation to another organism (crop plants) within the same habitat. Adaptation is a change or a process of change by which an organism becomes better suited to a "new" environment, whereas tolerance is the ability of an organism to survive and reproduce under adverse environmental conditions. Weediness, which comprises traits that secure the survival and dispersal of weeds, even under severe environmental conditions, can be described through various morphological, phenological, or physiological characteristics. One of the main components of integrated weed management strategies for farmers is to grow crops able to offset the competitive ability of weeds. The utility of crops with weed-suppressive ability particularly in low input agricultural systems, or in situations when chemical weed control is not possible, can be proven valuable (Gibson et al. 2003; Benaragama et al. 2014). However, selection for weed-suppressive cultivars is difficult because this trait is a manifestation of the joint activity of many genes, controlling many traits. As reports have shown, a combination of characteristics, instead of a single trait, interacts for enhanced weed-suppressive ability (Andrews et al. 2015). These traits are related to (a) crop morphological performance at early stages (i.e., rapid emergence, rapid root and shoot growth, early groundcover, early biomass accumulation, rapid leaf area development), (b) crop growth characteristics (i.e., height, growth habit, tillering ability, leaf width, maturity date), (c) crop physiological performance (i.e., ability for efficient water and nutrient uptake), and (d) potential allelopathic properties (Korres and Froud-Williams 2002; Korres 2005; Mason and Spaner 2006).

Climate change, in combination with an increasing world population, is predicted to escalate the global need for farmland, a resource that is already in high demand (Barrow et al. 2008) and dwindling rapidly. The adoption of stress-tolerant cultivars that can withstand adverse climatic changes and produce high yields is an effective strategy against the unprecedented risks of climate change on crop productivity (Ciais et al. 2005) and the increasing demand for higher food production (Larson 2013) particularly in low-input farming systems that are common in marginal areas (Darwin and Kennedy 2000). Furthermore, stress-tolerant cultivars that exhibit attributes of increased suppressive ability against weeds would secure yield production even more either directly by dominating over weeds or indirectly by reducing crop management inputs (Korres and Froud-Williams 2002). To our knowledge, information that enables the evaluation of the relative strengths and weaknesses of both crops and weeds under various climate change scenarios is negligible. This paper aims to cover this gap and to discuss the benefits of selecting stress-tolerant cultivar as a tool for integrated weed control under various climate change scenarios.

\section{Effects of climate change on crops}

\subsection{Effects of elevated $\mathrm{CO}_{2}$}

\subsubsection{Effects of elevated $\mathrm{CO}_{2}$ on crop physiological characteristics}

Increasing levels of atmospheric $\mathrm{CO}_{2}$ due to various anthropogenic activities will directly influence photosynthesis, 
transpiration, and respiration, the main processes by which elevated $\mathrm{CO}_{2}$ can be sensed directly by the plants and ecosystems (Drake et al. 1997). C3 and C4 plant types exhibit different responses to $\mathrm{CO}_{2}$ enrichment. The current amount of $\mathrm{CO}_{2}$ in the atmosphere is inadequate to saturate the ribulose-1,5biphosphate ( $\mathrm{RuBisCO})$ enzyme that drives photosynthesis in C3 plants (Taiz and Zeiger 1991; Chijioke et al. 2011). Therefore, future increases in $\mathrm{CO}_{2}$ concentrations up to $57 \%$ by 2050 (Hulme 1996), or even at higher levels (600$800 \mathrm{ppm}$ ) (Schmidhuber and Tubiello 2007), will most probably favor C3 plant types (Table 1). In contrast, $\mathrm{C} 4$ type plants are likely to respond less to elevated $\mathrm{CO}_{2}$ levels as they possess an innate concentrating mechanism that increases $\mathrm{CO}_{2}$ level at the site of RuBisCO to $2000 \mathrm{ppm}$. Hence, predicted increases in atmospheric $\mathrm{CO}_{2}$ concentrations, from a current ambient level of about $370 \mathrm{ppm}$, are less relevant to the photosynthetic capacity of C4 plants which, most probably, will respond only marginally (Poorter and Navas 2003). The association of photosynthesis rate and intercellular $\mathrm{CO}_{2}$ concentration was compared in soybean (C3) and maize (C4). Photosynthesis in soybean was stimulated by $39 \%$ under elevated $\mathrm{CO}_{2}$ concentration but not in maize (Leakey et al. 2009).

\subsubsection{Effects of elevated $\mathrm{CO}_{2}$ on crop yields}

Carbon dioxide is fundamental for plant production, and increases of atmospheric $\mathrm{CO}_{2}$ concentrations have the potential to enhance the productivity of agroecosystems (Table 1) (Adams et al. 1998). Elevated $\mathrm{CO}_{2}$ is expected to increase plant yield through root mass and leaf area increases (Table 1) and to alter plant chemical composition, hence the rate of nutrient cycling in soil (Campbell et al. 1997). Increases in marketable yield of cereals, particularly those that exhibit $\mathrm{C} 3$ photosynthetic pathway, range between 8 and $70 \%$; those of row, cash, and vegetable crops between 20 and $144 \%$; and those of flowers between 6 and $35 \%$ (Table 2). The quality of agricultural products may be altered also by elevated $\mathrm{CO}_{2}$. Nitrogen content, for example, in some non-nitrogen fixing plants grown at elevated $\mathrm{CO}_{2}$, was found reduced (Ainsworth and Long 2005; Erbs et al. 2010). These changes could affect the nutritional value, taste, and storage quality of some fruits and vegetables (Chijioke et al. 2011; Vermeulen et al. 2012).

\subsection{Effects of temperature increases}

\subsubsection{Effects of temperature increases on crop physiological characteristics}

Temperature increases result in altered phenology of leaf development, flowering, harvest and fruit production, decreased vernalization period, and in asynchrony between flowering and pollinators (Baldocchi and Wong 2008). In addition, increased temperatures result in higher respirations rates, shorter seed formation periods, and lesser biomass production, hence lower yields (Stone and Nicolas 1995; Adams et al. 1998). Key stages of crop development, seasonal temperature incidents, day-night temperature fluctuations, and geographical scale are the major parameters that should be taken under consideration when the effects of temperature on crop yields are evaluated. Only few days of extreme temperatures at the
Table 1 Response of $\mathrm{C} 3$ and $\mathrm{C} 4$ weeds and crops to doubled atmospheric $\mathrm{CO}_{2}$ levels in relation to biomass and leaf area production for both crop plants and weed species with $\mathrm{C} 3$ and $\mathrm{C} 4$ photosynthetic pathway

\begin{tabular}{|c|c|c|c|c|c|}
\hline C3 species & Biomass & Leaf area & C4 species & Biomass & Leaf area \\
\hline \multicolumn{6}{|c|}{ Range of response ( $\times$ growth at ambient $\mathrm{CO}_{2}$ concentrations) } \\
\hline Abutilon theophrastii & $1-1.52$ & $0.87-1.17$ & Amaranthus retroflexus & $0.9-1.41$ & $0.94-1.25$ \\
\hline Bromus mollis & 1.37 & 1.04 & Andropogon virginicus & $0.8-1.17$ & $0.88-1.29$ \\
\hline Bromus tectorum & 1.54 & 1.46 & Cyperus rotundus & 1.02 & 0.92 \\
\hline Cassia obtusifolia & $1.4-1.6$ & $1.1-1.34$ & Digitaria ciliaris & $1.06-1.6$ & $1.04-1.66$ \\
\hline Chenopodium album & $1-1.6$ & 1.22 & Echinochloa crus-galli & $0.95-1.6$ & $0.98-1.77$ \\
\hline Datura stramonium & $1.7-2.72$ & 1.46 & Eleusine indica & $1.02-1.2$ & $0.95-1.77$ \\
\hline Elytrigia repens & 1.64 & 1.3 & Paspalum plicatum & 1.08 & 1.02 \\
\hline Phalaris aquatic & 1.43 & 1.31 & Rottboellia cochinchinensis & 1.21 & 1.13 \\
\hline Plantago lanceolata & $1-1.33$ & 1.33 & Setaria faberii & $0.93-1.35$ & $1-1.4$ \\
\hline Rumex crispus & 1.18 & 0.96 & Sorghum halepense & $0.56-1.1$ & $0.99-1.3$ \\
\hline \multicolumn{6}{|c|}{ Range of response ( $\%$ increase) } \\
\hline Triticum aestivum & $17-31$ & & Zea mays & $3.7-9$ & \\
\hline Hordeum vulgare & 30 & & Sorghum bicolor & 9 & \\
\hline Glycine $\max$ & 39 & & & & \\
\hline Gossypium hirsutum & 84 & & & & \\
\hline Ipomoea batatas & 59-111 & & & & \\
\hline
\end{tabular}

Adopted from Chandrasena (2009), Patterson (1985), and Streck (2005) 
Table 2 Effects of doubling $\mathrm{CO}_{2}$ concentration on marketable yield of major cereal, row, cash, vegetable crops, and flowers

\begin{tabular}{ll}
\hline Crop & Marketable yield (\% increase) \\
\hline Maize $^{\mathrm{a}}$ & $3.7-29$ \\
Sorghum $^{\mathrm{a}}$ & 6 \\
Wheat $^{\mathrm{a}}$ & $8-35$ \\
Barley $^{\mathrm{a}}$ & 70 \\
Rice $^{\mathrm{a}}$ & 25 \\
Soybean $^{\mathrm{b}}$ & $22-45$ \\
Tobacco $^{\mathrm{b}}$ & 42 \\
Potato $^{\mathrm{b}}$ & 51 \\
Tomato $^{\mathrm{b}}$ & $20-26$ \\
Lettuce $^{\mathrm{b}}$ & $35-44$ \\
Cucumber $^{\mathrm{b}}$ & 30 \\
Sunflower $^{\mathrm{b}}$ & 144 \\
Chrysanthemum $^{\mathrm{c}}$ & 6 \\
Cyclamen $^{\mathrm{c}}$ & 35 \\
Rose $^{\mathrm{c}}$ & $8-27$ \\
\hline
\end{tabular}

Adopted from Streck (2005). Values shown in this table were obtained by the compilation and analysis of the results of more than 770 reports about the effects of $\mathrm{CO}_{2}$ enrichment on the economic yield of 24 agricultural crops and 14 other species

${ }^{a}$ Cereals, crops

${ }^{\mathrm{b}}$ Row, cash, and vegetables

${ }^{\mathrm{c}}$ Flowers

flowering stage can drastically reduce yield in many crops (Wheeler et al. 2000). Pre- and post-anthesis heat incidents at $35^{\circ} \mathrm{C}$ led to significant yield loss of barley, wheat, and triticale (Zheng et al. 2002; Porter and Semenov 2005; Ugarte et al. 2007). Increases in spring temperatures have been shown to induce earlier spring flowering (Pope et al. 2013) and reductions in pollen germination, flowering, and ovule size with subsequent fruit yield declines due to smaller, deformed, and fewer fruit production in perennial crops (Pope 2012; DeCeault and Polito 2008). Each crop species exhibits an optimal temperature for vegetative growth with growth decreasing as temperatures diverge from this optimum. Similarly, there is a range of temperatures within which a plant will set seeds and outside of which the plant will not be able to reproduce. Maize, for instance, will fail to reproduce at temperatures above $32^{\circ} \mathrm{C}$ and soybean above $38^{\circ} \mathrm{C}$ (Fig. 2). Consequently, the trend in India toward more production of wheat, rice, and barley, and less production of maize and millets, is likely to accelerate, whereas in the USA, production might shift away from maize into soybean (C3) for forage (Parry 1990). High temperatures (above $35^{\circ} \mathrm{C}$ ) in combination with high humidity and low wind speed caused a $4{ }^{\circ} \mathrm{C}$ increase in rice panicle temperatures, resulting in floret sterility (Tian et al. 2010).

\subsubsection{Effects of temperature increases on crop yield}

Crop yields particularly those of temperature-sensitive crops such as maize, soybean, wheat, and cotton (Schlenker and Roberts 2009) or specialty crops such as almonds, grapes, berries, citrus, or stone fruits (Lobell and Field 2011; Lobell et al. 2006) will be decreased with temperature increases at the regional and local scales (Lobell et al. 2006). Night temperature increases resulted in rice and wheat grain yield losses (Lobell et al. 2005; Peng et al. 2004; Mohammed and Tarpley 2009). Thus, even a C3 crop like rice which is expected to yield better under increased $\mathrm{CO}_{2}$ will suffer serious yield losses under high temperature. Since the majority of global rice is grown in tropical and semitropical regions, it is likely that higher temperatures would negatively affect its production in these areas due to an increase in floret sterility that would subsequently decrease yields (Prasad et al. 2006a, b). The detrimental effect of high temperature on rice yield will be exacerbated by increased $\mathrm{CO}_{2}$ in the atmosphere.

\subsection{Effects of water deficit}

\subsubsection{Effects of water deficit on crop physiological characteristics}

Physiological responses of plants to drought stress are complex and vary with plant species and the degree or time of the exposure to drought (Bodner et al. 2015; Evans et al. 1991). Under drought conditions, photosynthesis inhibition occurs
Fig. 2 Vegetative and reproductive response of maize and soybean to temperature increases (based on Karl et al. 2009)
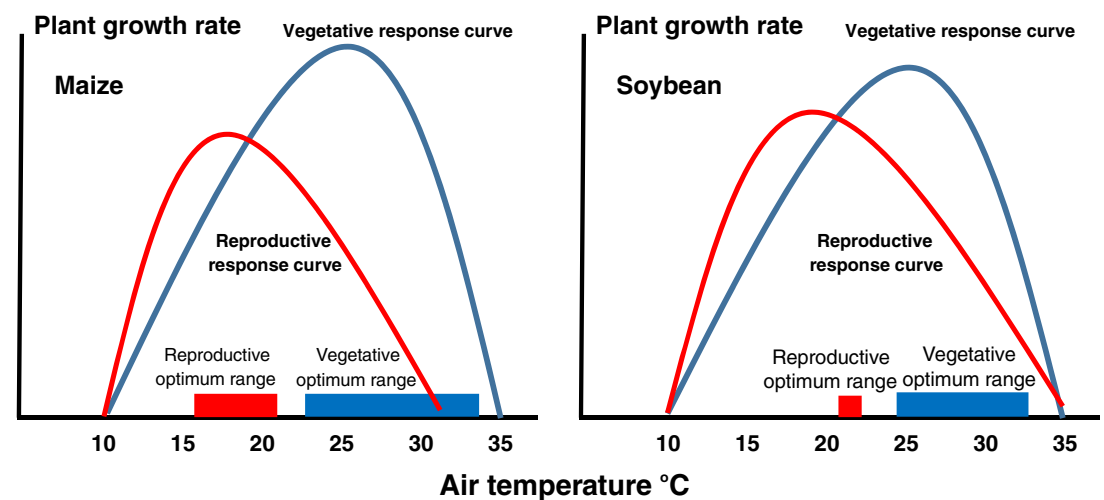
because of stomata closure and reductions in the $\mathrm{CO}_{2} / \mathrm{O}_{2}$ ratio in leaves (Griffin et al. 2004).

\subsubsection{Effects of water deficit on crop yield}

Significant crop yield reductions occur under drought stress through dry weight accumulation reductions in all plant organs and shorter plant life cycles (Blum 1996). Pace et al. (1999) recorded significantly fewer nodes, lower dry weights of stems, and reduction in height and leaf area between waterstressed and well-watered cotton plants (Table 3 ). In addition, water deficit at flowering may limit the viability of pollen, the receptivity of its stigma, and seed development (Blum 1996). Reduced yields, especially in rain-fed cropping systems, is the norm under drought conditions (Kramer 1983), the severity of which may increase due to changing world climatic trends (Le Houerou 1996). One possible scenario is that the irrigated wetland rice (13 Mha of cultivated land) in Asia may experience physical water scarcity by 2025 , while the irrigated dryseason rice (22 Mha of cultivated land) may suffer economic water scarcity (human, institutional, and financial capital limit access to water even though water in nature is available locally to meet human demands) (Tuong and Bouman 2003). Deleterious effects of water deficit on crops such as tomato (Ragab et al. 2007), soybean (Sakthivelu et al. 2008; Hamayun et al. 2010), maize (Khodarahmpour 2011), and many others are well known.

\subsection{Interactive effects of climate change components on the physiology of crop plants and yield}

In previous sections, the effects of climate change components on crop plants were examined individually although environmental changes occur concurrently (Albert et al. 2011) with management practices (Tubiello and Ewert 2002). For instance, crop yield response to elevated $\mathrm{CO}_{2}$ levels is relatively greater in rain-fed than in irrigated crops, due to a combination

Table 3 Plant height, stem and leaf dry weight, leaf area, and node number in drought-stressed and well-watered control cotton plants at the end of the drought (49 days after planting)

\begin{tabular}{lll}
\hline Plant part & \multicolumn{2}{l}{ Treatment } \\
\cline { 2 - 3 } & Drought $^{\mathrm{a}}$ & Control \\
\hline Plant height & 20.0 & 27.9 \\
Stem dry weight $(\mathrm{g})$ & 1.13 & 1.39 \\
Leaf dry weight $(\mathrm{g})$ & 1.41 & 2.16 \\
Leaf area $\left(\mathrm{cm}^{2}\right)$ & 56 & 153 \\
Node number & 7.8 & 9.4 \\
\hline
\end{tabular}

The drought treatment was imposed by withholding water for 13 days

${ }^{a}$ Means in a row are significantly different at the 0.05 probability level (based on Pace et al. 1999) of increased water-use efficiency (WUE) (Table 4) and root water uptake capacity (Tubiello and Ewert 2002). In addition, the projected increases in atmospheric $\mathrm{CO}_{2}$ concentration will increase crop growth and consequently nitrogen uptake by the crop, thus potentially will increase the need for fertilizer applications if production is to be maximized (Olesen and Bindi 2002). Elevated $\mathrm{CO}_{2}$ resulted in a sustained larger $\mathrm{N}$ pool in aboveground biomass of grasses during a 5-year study on long-term enhancement of $\mathrm{N}$ availability under $\mathrm{CO}_{2}$ concentration increases, suggesting that more $\mathrm{N}$ was taken up each year from the soil under elevated $\mathrm{CO}_{2}$ (Dijkstra et al. 2008). Also, increased soil moisture under elevated $\mathrm{CO}_{2}$ supported higher rates of $\mathrm{N}$ mineralization, thereby reducing $\mathrm{N}$ constraints on plant growth. More of the mineralized $\mathrm{N}$ ended up in the aboveground biomass of needle-and-thread [Hesperostipa comata (Trin. \& Rupr.) Barkworth] (C3) than in blue grama [Bouteloua gracilis (Willd. ex Kunth) Lag. ex Griffiths] (C4) under elevated $\mathrm{CO}_{2}$ (Dijkstra et al. 2008). Therefore, it is possible that $\mathrm{C} 3$ species exhibit a higher plant $\mathrm{N}$ acquisition and utilization under elevated $\mathrm{CO}_{2}$ concentrations. Ghannoum (2009) reviewed the $\mathrm{C} 4$ photosynthesis response to water stress in interaction with $\mathrm{CO}_{2}$ concentration and reported that elevated $\mathrm{CO}_{2}$ concentration lessens the deleterious effect of drought on plant productivity. This is due to reduced stomatal conductance, $\mathrm{CO}_{2}$ assimilation rate, and intercellular $\mathrm{CO}_{2}$ levels (Ghannoum 2009; Ripley et al. 2007); therefore, saturating $\mathrm{CO}_{2}$ concentration keeps the photosynthetic capacity unchanged and limits reductions in plant productivity.

\section{Effects of climate change on weeds}

Compared with crops, weeds have more variable characteristics as they have not been subjected to the same degree of selection for specific favorable traits (e.g., lack of seed

Table 4 Seasonal water use efficiency (g DM/kg water) under various water regimes and ambient and double $\mathrm{CO}_{2}$ concentrations in various crop species

\begin{tabular}{llll}
\hline & Ambient $\mathrm{CO}_{2}$ & Double $\mathrm{CO}_{2}$ & Ratio \\
\hline Sorghum & 3.08 & 4.13 & 1.34 \\
Wheat (well watered) & 5.1 & 6.3 & 1.23 \\
Wheat (water shortage) & 6.2 & 8.9 & 1.43 \\
Wheat & 2.62 & 3.45 & 1.31 \\
Wheat (well watered) & 1.58 & 2.14 & $1.35^{\mathrm{a}}$ \\
Wheat (water shortage) & 1.27 & 1.86 & $1.46^{\mathrm{a}}$ \\
Faba beans & 4.91 & 7.82 & 1.59 \\
Water hyacinth & 1.4 & 2.6 & 1.85 \\
\hline
\end{tabular}

Adopted from Morison (1993)

${ }^{\mathrm{a}}$ Grain only 
dormancy, uniform growth, high yields). Hence, weeds tend to exhibit greater potential capability to adapt to stress than crop plants. The high genetic diversity among weedy plants allows them to achieve a greater competitive fitness against crops as a consequence of climate change (Dukes and Mooney 1999). The major categories under which climate change will affect weed populations include species abundance and richness, geographic range, and phenology (Anonymous 2013; Curtis and Wang 1998).

\subsection{Effects of elevated $\mathrm{CO}_{2}$}

\subsubsection{Direct effects of elevated $\mathrm{CO}_{2}$ on weeds}

There is an acknowledged consensus regarding the direct impact of increased $\mathrm{CO}_{2}$ on plant physiology (Ziska 2004). Many weeds respond positively to elevated $\mathrm{CO}_{2}$ due to decreased stomatal conductance (Bunce 1998) and subsequent improvements in water-use efficiency (Patterson et al. 1999; Ziska and Runion 2006). C3 plant types are likely to respond more strongly than $\mathrm{C} 4$ plant types to $\mathrm{CO}_{2}$ increases (Southworth et al. 2002; Ziska 2004) (Fig. 3) through biomass and leaf area increases (Walthall et al. 2012). Nonetheless, results from various studies indicate significant and wide variations in response to elevated $\mathrm{CO}_{2}$ due to interactions with temperature, light, water, and nutrients. $\mathrm{CO}_{2}$ enrichment enhanced the growth and biomass production of annual fescue [Vulpia myuros (L.) C.C. Gmel.] (C3 type), Santa Maria feverfew weed (Parthenium hysterophorus L.) (C3/C4 intermediate type), and green amaranth (Amaranthus viridis L.) (C4 type) (Scott et al. 2014; Naidu and Paroha 2008). Other direct effects of elevated $\mathrm{CO}_{2}$ are the production of excess pollen in ragweed (Ambrosia artemisiifolia L.) (Wayne et al. 2002) and

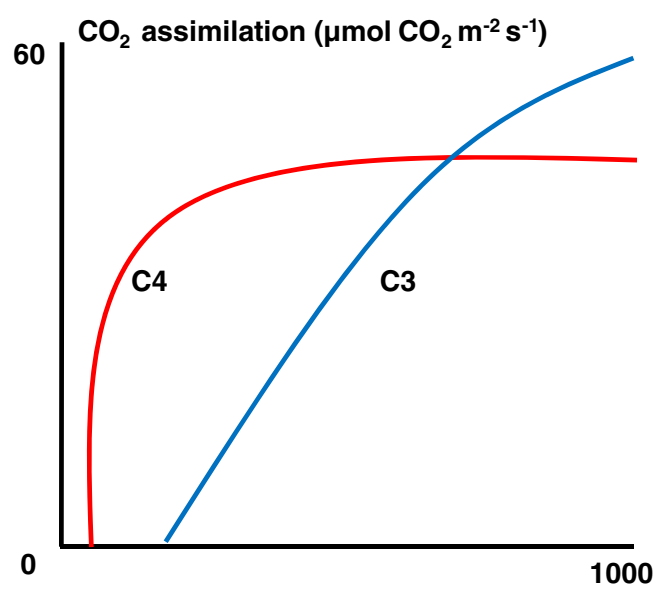

Ambient $\mathrm{CO}_{2}$ concentration ( $\mu$ bars)

Fig. 3 Response of $\mathrm{CO}_{2}$ assimilation in $\mathrm{C} 3$ vs. $\mathrm{C} 4$ plants to increases in $\mathrm{CO}_{2}$ concentration (based on Taiz and Zeiger 1991) the accelerated maturity rate in wild oat (Avena fatua L.) (Anonymous 2008).

\subsubsection{Indirect effects of elevated $\mathrm{CO}_{2}$ on weeds}

Weed reproductive capacity will most probably be enhanced by increased $\mathrm{CO}_{2}$ (Patterson et al. 1999; Ziska and Runion 2006). In case of the green amaranth, a $274 \%$ increase in flower production under elevated $\mathrm{CO}_{2}(550 \pm 30 \mathrm{ppm})$ in controlled environmental conditions was reported by Naidu and Paroha (2008). Reproductive capacity is linked to resource capture (DeFelice et al. 1988; Benvenuti and Steffani 1994; Bello et al. 1995) which is related to increased biomass and leaf area (Korres 2005). Therefore, increases in biomass with elevated $\mathrm{CO}_{2}$ levels will enhance weed reproductive output as these two traits are positively correlated (Korres and FroudWilliams 2002; Korres and Norsworthy 2015). Hence, increases in reproductive output will result in increases of weed abundance. Disruptions of soil and native plant populations for urban or rural development, emissions that increase atmospheric $\mathrm{CO}_{2}$ concentrations, and nitrogen deposition to the ground surface which enhance weed growth (Johnson and Council 2013), and roadside activities which lead to the spread of weeds (Korres et al. 2015) will further enhance weed abundance. In addition, Ziska et al. (2004) observed that elevated $\mathrm{CO}_{2}$ concentrations increased root biomass of Canada thistle (C3 plant type), suggesting that perennial weeds might be more difficult to control at these higher $\mathrm{CO}_{2}$ levels.

\subsubsection{Effects of elevated $\mathrm{CO}_{2}$ on crop-weed interference}

Some of the world's most troublesome weed species are C4 types and are found in C3 crops (Edwards and Huber 1981). The positive response of $\mathrm{C} 3$ crops to increased $\mathrm{CO}_{2}$ may make such weeds less competitive (Table 5). In contrast, C3 weeds in $\mathrm{C} 4$ or $\mathrm{C} 3$ crops, particularly in tropical regions, could become a problem (Table 5), although the final outcome will depend on other climate change components (Morison 1989). Despite the fact that many weed species exhibiting a $\mathrm{C} 4$ photosynthetic pathway show less response to atmospheric $\mathrm{CO}_{2}$ relative to $\mathrm{C} 3$ crops, in most agronomic situations, a mix of both $\mathrm{C} 3$ and $\mathrm{C} 4$ weeds occurs. As stated earlier, increases in $\mathrm{CO}_{2}$ concentrations will enhance $\mathrm{C} 3$ weed growth particularly for those species that reproduce by vegetative means (Ziska and George 2004; Ziska 2003). Consequently, the abundance of perennial weeds such as common couch [Elytrigia repens (L.) Desv. Ex. Nevski], heartshape pickerelweed [Monocharia vaginalis (Burm. F.) Presl], cosmopolitan bulrush [Scirpus maritimus L.], hedge bindweed [Calystegia sepium (L.) R. Br.], Canada thistle [Cirsium arvense (L.) Scop], perennial sowthistle [Sonchus arvensis L.], and horsenettle [Solanum carolinense L.], most of them found in rice or soybean 
Table 5 Response of crop and weed species grown under competition as a function of high $\mathrm{CO}_{2}$ concentration

\begin{tabular}{lll}
\hline C4 weed vs. C3 crops & High $\mathrm{CO}_{2}$ favors & Environment \\
\hline Sorghum halepense vs. Festuca pratensis & Crop & Greenhouse \\
Sorghum halepense vs. Glycine max & Crop & Growth chamber \\
Amaranthus retroflexus vs. Glycine max & Crop & Field \\
Echinochloa glabrescens vs. Oryza sativa & Crop & Greenhouse \\
Paspalum dilatatum vs. various grasses & Crop & Growth chamber \\
Various grasses vs. Medicago sativa & Crop & Field \\
C3 weed vs. C3 crops & & \\
Chenopodium album vs. Beta vulgaris & Crop & Growth chamber \\
Taraxacum officinale vs. Medicago sativa & Weed & Field \\
Plantago lanceolata vs. pasture & Weed & Growth chamber \\
Taraxacum and Plantago vs. pasture & Weed & Field \\
Cirsium arvensis vs. Glycine max & Weed & Field \\
Chenopodium album vs. Glycine max & Weed & Field \\
C4 weed vs. C4 crop & & \\
Amaranthus retroflexus vs. Sorghum bicolor & Weed & Field \\
C3 weeds vs. C4 crops & & \\
Xanthium strumarium vs. Sorghum bicolor & Weed & Greenhouse \\
Abutilon theophrasti vs. Sorghum bicolor & Weed & Field \\
\hline
\end{tabular}

Based on Brunce and Ziska (2000) and Walthall et al. (2012) cropping systems, may increase, since elevated $\mathrm{CO}_{2}$ stimulates greater rhizome and tuber growth (Chandrasena 2009).

\subsection{Effects of temperature}

\subsubsection{Effects of temperature on weed physiological characteristics}

Soil temperature is the primary determinant of seed germination and survival particularly when soil freezes (Zimdahl 2007). Various responses to temperature fluctuations have been reported for seed germination of weed species. Common chickweed (Stellaria media L.) survives well in cold climates (King 1966), whereas some of the most troublesome weeds in soybean, maize, and cotton respond to temperature gradients to varying degrees (Ehleringer 1983). Barnyardgrass (Echinochloa spp.) is a weed of warm regions that requires high temperatures for dry matter production and growth (Maun and Bennett 1986). Similarly, prickly sida (Sida spinosa L.) needs high temperatures for its development (Anonymous 2001). The spatial distribution of johnsongrass [Sorghum halepense (L.) Pers.] in colder climates is restricted by its rhizome intolerance to temperatures below $-3{ }^{\circ} \mathrm{C}$ (Warwick and Black 1983). Similarly, morning glories are frost intolerant (Halvorson and Guertin 2003; Zia-Ul-Haq et al. 2012), but their germination occurs over a wide range of temperatures $\left(15-35{ }^{\circ} \mathrm{C}\right)$ (Cole and Coats 1973 - cited in Halvorson and Guertin 2003) with optimum germination temperature at $24{ }^{\circ} \mathrm{C}$ (Crowley and Buchanan 1980 - cited in
Halvorson and Guertin 2003). In addition, Ziska and Bunce (2007) reported $88 \%$ increase in biomass and $68 \%$ increase in leaf area of itchgrass [Rottboelliia cochinchinensis (Lour.) W.D. Clayton] in response to a $3{ }^{\circ} \mathrm{C}$ increase in temperature.

\subsubsection{Effects of temperature on weed distribution}

The geographical range of many weed species is largely determined by temperature and it has long been recognized that temperature determines successful colonization of new environments by weedy species (Woodward and Williams 1987). Warming will affect the growth, reproduction, and distribution of weeds. Increased temperatures could, for example, alter the latitudinal distinction between Midwest and Midsouth regions within the USA, altering the weed geographical limitations. The greater soybean and maize losses experienced in the Midsouth are associated with a number of very aggressive weed species of tropical or subtropical environments such as prickly sida and johnsongrass (Osunsami 2009; Riar et al. 2013). Obviously, increased temperatures will facilitate the spread of these species into other areas of the Midwest with subsequent effects on soybean and maize production (Walthall et al. 2012). Temperature increases are likely to be particularly important in affecting the relative plant growth of $\mathrm{C} 3$ and $\mathrm{C} 4$ plants, potentially favoring C4 weeds (Dukes and Mooney 1999), such as smutgrass (Sporobolus indicus L. R. Br.). This again could provide suitable conditions for more robust growth of some species, which are currently limited by low temperatures, whereas the distribution of some tropical and 
subtropical C4 species could shift northwards (Ziska and Runion 2006; Chandrasena 2009), thus exposing temperatezone agriculture to previously unknown aggressive colonizers.

In addition, Ziska and Bunce (2007) stated that an expansion of invasive weed species such as itchgrass, cogongrass [Imperata cylindrical (L.) P. Beauv.], and witchweed [Striga asiatica (L.) Kuntze] will be facilitated by temperature increases. They also reported an increase in biomass and leaf area of itchgrass by 88 and $68 \%$, respectively, in response to a $3{ }^{\circ} \mathrm{C}$ increase. On the contrary, additional warming could restrict the southern range of other cooler climate invasive weeds such as wild proso millet (Panicum miliaceum L.) or Canada thistle (Ziska and Runion 2007).

\subsection{Effects of water deficit}

\subsubsection{Effects of drought on weed physiological responses}

Under more frequent and severe drought stress events due to climate change, the competitive balance would shift in favor of deep-rooted plants (Stratonovitch et al. 2012). Early emerging species, such as the shallow-rooted Sandberg's bluegrass (Poa sandbergii Vasey), which uses the resources that are available in the upper soil profile early in the growing season and during periods of light precipitation, will be suppressed (Daudenmire 1970 cited in Sheley et al. 1996).

In addition, dry soil conditions prolong the longevity of weed seeds due to unfavorable conditions for seed predators (Storrie and Cook 2007) and unfavorable conditions for germination. Weed seeds such as black bindweed (Polygonum cilinode Michx.) can last up to 7 years in the soil under dry conditions (Storrie and Cook 2007). A summary of the potential impacts of drought stress on some of the most important Australian weeds are shown in Table 6 where a trend of establishment in higher latitudes is expected (Anonymous 2008).

Table 6 Potential effects of drought on Australian agricultural weeds

\subsubsection{Weed adaptation strategies under water deficit and other unfavorable conditions}

As reported by Wiese and Vandiver (1970), species with the greatest growth under high soil moisture conditions will be the most adversely affected by the combination of competition and water shortage. On the contrary, the more competitive species under semidrought conditions are likely to be those that produce little growth in moist soils. Based on the competitive exclusion principle, the species that uses a resource more efficiently will eventually, either wholly or partially, displace the other species. This opportunistic behavior characterizes the r-strategists, those with short life cycle and high energy investments into reproduction and dispersability, as opposed to K-strategists (Sheley et al. 1996; Hardin 1960). Grime (1979) extended the r- and K-classification strategies into stress tolerators $(\mathrm{S})$, competitors $(\mathrm{C})$, ruderals $(\mathrm{R})$, or combinations of the above strategies. Under high stress intensity that can limit plant growth, as in the case of water or nutrient shortage, stress tolerators (S) can perform adequately. Based on the ability of adjacent organisms to exploit the same resource, competitors (C) will perform best, whereas ruderals (R) can withstand physical damages. Most weeds of annual agricultural systems exhibit ruderal-competitive characteristics, whereas most weeds of rangeland and forest ecosystems exhibit stress tolerance-competitive characteristics. Typically, succession is evolved from ruderal to competitive and finally to stress tolerator species (Korres 2005). Hence, under water or nutrient shortage scenarios, an $\mathrm{r}$-strategist with characteristics in the order S-C-R will most probably prevail. In a recent weed survey (Korres et al. 2015), the preference of Palmer amaranth, large crabgrass (Digitaria sanguinalis L. Scop.), johnsongrass, and spurges (Euphorbia spp.) for disturbed habitats was reported. In the same survey, giant ragweed (Ambrosia trifida L.), yellow nutsedge (Cyperus esculentus L.), barnyardgrass, and hemp sesbania [Sesbania herbacea (Mill.) McVaFugh] exhibited a strong preference for moist habitats. Obviously, the former group of weeds is assured of a greater probability for survival under water or nutrient stress conditions in comparison to the latter.

\begin{tabular}{ll}
\hline Weed & Impact \\
\hline Blackberry (Rubus fruticosus L.) & $\begin{array}{c}\text { Expected to retreat to higher altitudes due to its sensitivity to higher } \\
\text { temperatures and drought }\end{array}$ \\
$\begin{array}{ll}\text { Chilean needle grass [Nassella neesiana } \\
\text { (Trin. \& Rupr.) Barkworth)] }\end{array}$ & $\begin{array}{c}\text { Exped to increase its range because its increased invasiveness } \\
\text { ability (long-lived, seed dispersed by wind and water) and } \\
\text { drought tolerance }\end{array}$ \\
Gorse (Ulex europaeus L.) & $\begin{array}{c}\text { Establishment into high-rainfall zones due to its sensitivity to } \\
\text { drought }\end{array}$ \\
Lantana (Lantana camara L.) & Establishment into high-rainfall zones \\
\hline
\end{tabular}

Adopted from Anonymous (2008) 


\subsection{Interactive effects of climate change components on weed performance and consequences on weed-crop competition}

The influence of climate change on simple competitive outcomes will be difficult to predict based simply on a single model, as interactions between the various climate change scenarios are likely to concur and will affect the outcome of the crop-weed competition (Alberto et al. 1996). The growth of a tropical weed is strongly stimulated by relatively small changes in air temperature (Patterson et al. 1984), but the potential synergistic effects of rising $\mathrm{CO}_{2}$ on these weeds relative to tropical crops are unknown. It is believed that increased $\mathrm{CO}_{2}$ and temperature can negatively impact plant growth. Scott et al. (2014), for example, reported that increases in both parameters negatively impacted plant growth rates in grassland ecosystems. The effects of elevated $\mathrm{CO}_{2}$ levels on crops and weeds will alter the weed-crop competitive interactions, sometimes for the benefit of the crop and sometimes for the weeds. Consequently, the control of weeds will also likely be affected by these changes (Patterson 1995; Coakley et al. 1999). Reduction in transpiration and changes in leaf anatomy and leaf surface characteristics, or greater root to shoot ratio caused by elevated $\mathrm{CO}_{2}$, could also affect herbicide uptake, thus reducing herbicide efficiency (Patterson et al. 1999; Olesen and Bindi 2002; Poorter and Navas 2003; Dukes et al. 2009). This was confirmed by various studies in which increased $\mathrm{CO}_{2}$ concentration has affected the efficacy of glyphosate on both $\mathrm{C} 3$ and $\mathrm{C} 4$ weed photosynthetic types (Ziska et al. 1999, 2004; Manea et al. 2011) (Table 7). This response to carbon dioxide in combination with the evolution of glyphosate resistance by many weed species (Heap 2015) will affect weed control schemes significantly. Controlling weeds currently costs the USA, more than $\$ 11$ billion a year, with the majority spent on herbicides; hence, both herbicide use and costs are likely to increase as temperatures and carbon dioxide levels rise (Karl et al. 2009).

Additionally, little attention has been focused on the interactions between nutrient availability or drought with rising
$\mathrm{CO}_{2}$, on weed-crop competition. According to Newton et al. (1996), the proportion of weed biomass increased with elevated $\mathrm{CO}_{2}$ equally in wet and dry treatments in pasture mixture. In another study, reduced weed competition was observed when tomato ( $\mathrm{C} 3 \mathrm{crop})$ and redroot pigweed ( $\mathrm{C} 4$ weed) were grown under well-watered conditions, but when drought and high $\mathrm{CO}_{2}$ occurred synchronously, redroot pigweed performed better (Valerio et al. 2011). Under extreme nutrient limitations, stimulation of biomass with additional $\mathrm{CO}_{2}$ may be minimal. However, under moderate nutrient limitations, more indicative of agroecosystems, the increase in biomass may be reduced but still occurs (Seneweera et al. 1994). Under a competitive environment between rice (C3 crop type) and barnyardgrass ( $\mathrm{C} 4$ weed type), the proportion of rice biomass increased relative to barnyardgrass with a 200 -ppm increase in atmospheric $\mathrm{CO}_{2}$, but only when soil nitrogen was adequate. If nitrogen was limited in an enriched $\mathrm{CO}_{2}$ environment, the competitive ability of rice relative to barnyardgrass was reduced, possibly due to reductions in tiller formation (Zhu et al. 2008). Elevated $\mathrm{CO}_{2}$ can mitigate some of the adverse effects of increased temperature and drought and also regulate the adaptive mechanism of black knapweed (Centaurea nigra L.) (Qaderi et al. 2013). The effects of drought are likely to vary widely among crops and weeds. In maize, drought has been found to both decrease interference from naturally occurring weed flora dominated by foxtail species (Setaria spp.) (McGiffen et al. 1997), and increase the competitive ability of johnsongrass (Leguizamon et al. 2011). Drought and high temperatures favor the competitive ability of C4 weeds over C3 crops (Fuhrer 2003), an advantage which will most probably diminish or possibly be reversed under increased $\mathrm{CO}_{2}$ concentrations (Bazzaz and Carlson 1984; Carter and Peterson 1983).

Spatial-based effects of temperature increases and prolonged drought periods on weeds have also been anticipated. More particularly, long drought periods interspersed with occasional very wet years will enhance weed invasion because established vegetation, both native and crops, will be weakened, leaving some areas open to invasion (Chandrasena
Table 7 Effects of increased $\mathrm{CO}_{2}$ concentration on glyphosate efficacy for various weed species with different photosynthetic pathways

\begin{tabular}{llll}
\hline Common name & Latin name & P/S pathway & Efficacy change \\
\hline Canada thistle & Cirsium arvense (L.) Scop & $\mathrm{C} 3$ & Reduced \\
Dallisgrass & Paspalum dilatatum Poir. & $\mathrm{C} 4$ & Reduced \\
Lambsquarters & Chenopodium album L. & $\mathrm{C} 3$ & Reduced \\
Lovegrass & Eragrostis curvula (Schrad.) Nees & $\mathrm{C} 4$ & Reduced \\
Quackgrass & Elytrigia repens (L.) Gould & $\mathrm{C} 3$ & Reduced \\
Redroot pigweed & Amaranthus retroflexus L. & $\mathrm{C} 4$ & None \\
Rhodes grass & Chloris gayana Kunth & $\mathrm{C} 4$ & Reduced \\
Smut grass & Sporobolus indicus (L.) R. Br. & $\mathrm{C} 4$ & None \\
\hline
\end{tabular}

Adopted from Ziska (2014a, b)

P/S pathway photosynthetic pathway 
2009). In general, wetter and milder winters are likely to increase the survival of some winter annual weeds, whereas warmer summers and longer growing seasons may permit thermophile summer annuals to grow in regions further north (Peters et al. 2014). Alterations in temperature and nutrients supply can reduce photosynthetic rate of Palmer amaranth. The combination of temperature between 36 and $46^{\circ} \mathrm{C}$ with resource supply constraints may restrict the potential distribution range of Palmer amaranth (Ehleringer 1983; Ward et al. 2013).

\section{Cultivar selection against weeds and traits that confer competitiveness}

Crop ability to suppress weeds can be considered in two ways, namely (a) the ability to tolerate weed competition which can be measured by the ability of the crop to maintain high yields under weedy conditions and (b) the ability of the crop to suppress the growth of weeds, usually determined by comparing different biological characteristics in mixtures with that in pure stands, known as weed suppression ability or competitive ability (Callaway 1992; Korres and Froud-Williams 2004; Andrews et al. 2015). However, there is a confusion between cultivar tolerance to weed competition and cultivar weedsuppressive ability (Olesen et al. 2004). Furthermore, crop tolerance to weed competition varies widely over seasons and locations (Cousens and Mokhtari 1998; Olesen et al. 2004). Thus, weed suppression criterion has been emphasized here for the selection of suitable cultivars against weeds under various climate change scenarios.

\subsection{Cultivar phenotypic characteristics and weed suppression}

Unlike breeding for diseases and pest resistance, little research has been done on breeding crop cultivars which are more competitive to weeds. Certain crop cultivars are known to be better competitors with weeds than others (Callaway 1992). For example, white bean (Phaseolus vulgaris L.) cultivars differ in their ability to compete with weeds (Malik et al. 1993). Certain tomato cultivars (Lycopersicon esculentum L.) have considerable tolerance to dodder (Cuscuta spp.), a severe parasitic weed in many parts of the world (Goldwasser et al. 2001). Cultivars of small grain cereals with certain characteristics such as short stature, earlier maturity, better winter hardiness, or early season growth have shown differential competitive abilities when grown in mixtures compared to monocultures (Juskiw et al. 2000). As stated by various authors, breeding crop cultivars with an enhanced ability to suppress weeds would be a sustainable contribution to improved weed management in many crops (Didon and Bostrom 2003; Lemerle et al. 2001; Paolini et al. 1998; Vollmann et al. 2010). Therefore, cultivar selection with traits that enhance its ability to suppress weeds such as these mentioned above could be explored under various climate change scenarios. Additionally, the belowground traits such as root length density, root elongation rate, total root length, and root spatial distribution are important factors for attributing competition effect (Gealy et al. 2013a; Fargione and Tilman 2006; Stevanato et al. 2011). The greater ability to extract water from dry soil may affect or even determine the competitive ability of a cultivar (Song et al. 2010). Reports have shown that under weed competition, the root/shoot ratio of the crop and weeds was reduced (Kasperbauer and Karlen 1994; Thomas and Allison 1975; Stone et al. 1998), particularly of the less competitive species, although soil water content was not a limiting factor (Thomas and Allison 1975; Rajcan and Swanton 2001). However, as stated by Rajcan and Swanton (2001), competition for water should be viewed as an outcome of the interaction between both soil-plant-atmosphere and the crop-weed systems, rather than simply as a shortage of available water.

\subsection{Implications for allelopathic properties}

Weed suppression can vary with management factors such as planting method, seeding density, flood depth, and nitrogen fertilization, whereas in some cases, activated charcoal has reduced the inhibition of weeds in soils, implicating allelopathic activity as a possible contributing factor (Kong et al. 2008, 2011). Rondo, for example, a rice cultivar grown in a commercial organic rice production operation in Texas, USA, that combines a high yield potential and a weed suppression ability, is considered as a potential cultivar with allelopathic properties (Gealy and Yan 2012). Bertholdsson (2010) bred spring wheat for improved allelopathic potential by conventional breeding. The material used originated from a cross between a Swedish cultivar with low allelopathic activity and a Tunisian cultivar with high allelopathic activity.

Therefore, research efforts have focused on combining allelopathic activity with other weed-suppressive traits in small grains such as rice (Fig. 4). Breeders in Asia showed that allelopathic traits in rice can be quantitatively inherited (Chen et al. 2008) and weed-suppressive cultivars have now been developed in that region (Kong et al. 2011; Ma et al. 2006; Pheng et al. 2009a, b). Similar progress has been reported in the USA (Gealy et al. 2013b). Breeding efforts with other small grains in Europe, using a dual screening approach of seedling bioassays for allelopathic potential coupled with field evaluations for general weed suppression, have resulted in germplasm with improved weed suppression or tolerance (Bertholdsson 2005, 2007, 2010). It has been reported that early season crop biomass and allelopathic potential were key traits for improved weed suppression by the crop 
Fig. 4 Rice weed suppression plots at Stuttgart, Arkansas, USA, in which the superior competitiveness of cultivars STG06L-35-061 and PI312777 compared with Katy and Lemont is shown. A "light" infestation of barnyardgrass can be observed in the former compared to later plots. No herbicide was used to control grass weeds (with permission from D. R. Gealy, USDA-ARS)
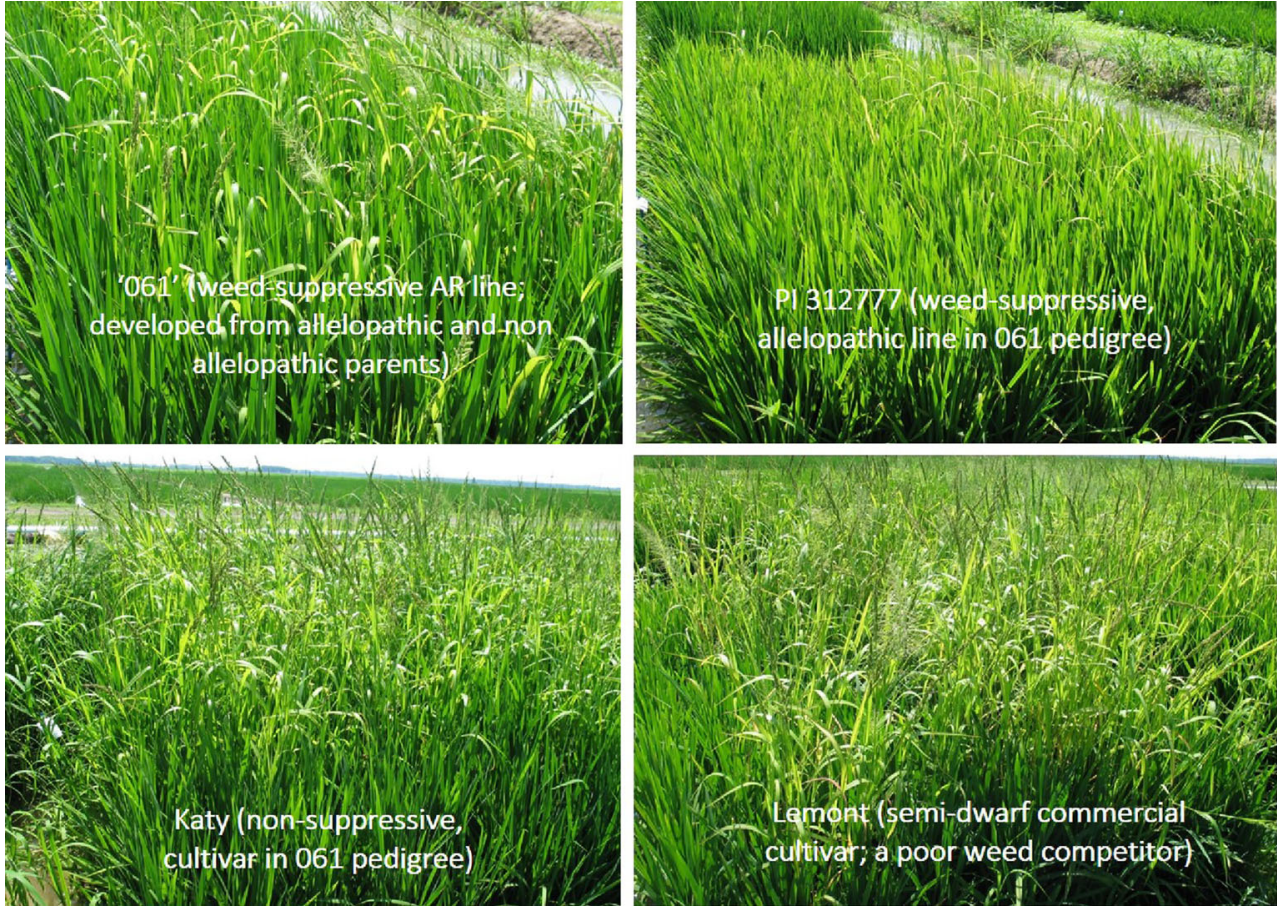

(Bertholdsson 2011; Bertholdsson et al. 2012). Worthington and Reberg-Horton (2013) have reviewed important breeding issues for small grains associated with optimization of weedcompetitive ability and allelopathic traits. Rice traits such as rapid seedling growth, leaf area, and tiller production and high yield potential have improved weed suppression and minimized crop yield loss (Gealy and Moldenhauer 2012; Gealy and Yan 2012; Gibson et al. 2003; Pérez de Vida et al. 2006). Zhao et al. (2006) successfully selected cultivars for weedsuppressive traits such as yield, early vigor, and height under weed-free conditions to identify weed-competitive cultivars.

\section{Traits for developing an ideotype S-C cultivar}

The use of tolerant cultivars to a wide range of climatic fluctuations as adaptive tool is widely spread (Matthews et al. 1994). In Australia, for example, the use of late-maturing cultivars secures high yield outcomes that could be otherwise affected by inconsistent climatic conditions (Connor and Wang 1993). A similar strategy, at the crop level, is used in Canada and China, where the diversification of crops counteracts the climatic fluctuations (Hulme et al. 1992; Cohen et al. 1992).

\subsection{Cultivars with deep root system}

Adapting a cultivar with a deep root system, particularly in areas which experience prolonged dry periods, can be a useful tool (Bodner et al. 2015). Newly introduced wheat cultivars can better exploit water and nutrients (Korres et al. 2008) mainly due to their greater ability to maintain water uptake and consequently to survive longer in dry soils (Song et al. 2009). Sorghum, for example, seems an attractive option for dry lands where crops frequently encounter drought stress compared to maize. Sorghum has deep root system, high root density, cuticle and epicuticular deposition in leaves, and efficient stomata function under water stress (Assefa et al. 2010; Starggenborg et al. 2008; Schittenhelm and Schroetterm 2014). Traits related to competitiveness for water and nutrients that could affect the weed-suppressive ability of the crop include root density, root length, water uptake rate, and root surface area (Aarssen 1989; Callaway 1992; Mohler 2001). In the long term, breeding drought-tolerant cultivars might be advantageous for weed suppression as well as a means to cope with climatic changes in areas with prolonged summer dry periods (Bodner et al. 2015). Acquiring and utilizing water and nutrients more adequately compared to weeds due to their extensive root system, for example, will enable crop cultivars to maintain growth even under drought conditions. Cultivars with high early vigor and earlier maturity can be used as an effective adaptation strategy for areas with semiarid continental climates in temperate zones where more frequent generative droughts are forecasted (Gouache et al. 2012; Bodner et al. 2015). Genetic manipulation using molecular breeding has resulted in commercialization of drought-resistant crops such as the maize-DroughtGrade ${ }^{\mathrm{TM}}$ (Monsanto, St. Louis, USA) that is already used extensively in the USA (Waltz 
2014). Differences in resistance to drought are known to exist within genotypes of plant species (Grzesiak et al. 2012), e.g., in wheat (Winter et al. 1988; Paknejad et al. 2007), rapeseed (Richards and Thurling 1978), oat (Larsson and Gorny 1988), and triticale (Royo et al. 2000; Grzesiak et al. 2012). Nevertheless, drought tolerance does not necessarily provide competitive advantages to the crop. As reported by Cerqueira et al. (2013), two drought-tolerant upland rice cultivars were affected by the competition of shrubby false buttonweed (Spermacoce verticillata L.) regardless of water conditions (presence and absence). In addition, as reported by Chauhan and Abugho (2013), rain-fed rice plants under weed competition with spiny amaranth (Amaranthus spinosus L.) and Chinese sprangletop [Leptochloa chinensis (L.) Nees] (C4 types) did not survive under limited water conditions. On the contrary, both weed species survived and produced a significant number of tillers and leaves.

\subsection{Harvest index and dry mater components}

To promote adaptation to high temperatures, plant breeders have suggested phenotypic traits related to heat tolerance during flowering, high harvest index, small leaves, and reduced leaf area per unit of ground area (Walthall et al. 2012). Differences between winter wheat cultivars in harvest index at high temperatures imply that heat-tolerant cultivars maintain higher grain development, compared to more temperature-sensitive cultivars (Wardlaw and Moncur 1995). Lower harvest indices are an indication of injudicious investment of assimilates, a result of favoring biomass production over commercial yield (Hay and Walker 1992). Therefore, genotypes with high harvest indices are expected to be weak competitors because of the relative fewer resources allocated for stem and leaf expansion (Kawano and Jennings 1983), traits that confer competitiveness. Mann (1980) stated that it might be possible to obtain improvements in harvest index and therefore yield, suggesting further reductions in straw length and maintenance of aboveground biomass. Korres (2000) investigating winter wheat cultivar characteristics for increased competitive ability found a negative relationship between the number of leaf area per square meter and infertile tillers per square meter. Questions that merit further thought are related to the manipulation of leaf area and infertile tiller production. If the production of infertile tillers could be manipulated, would this result in leaf area investments? Would increases in leaf area, hence interception of photosynthetic active radiation, in response to increased day length as the crop enters reproductive development cause higher yield production and enhance competitive ability? Would leaf area duration be affected and what would be the consequences for grain yield?

However, specific leaf area, a characteristic which is positively correlated with relative growth rate, is usually reduced by elevated $\mathrm{CO}_{2}$ thereby counteracting the positive response of photosynthesis (Bruhn et al. 2001).

\subsection{Late-maturing cultivars}

Late-maturing soybean cultivars (group IV) depressed weed seed production and seed weight of both pitted morning glory (Ipomoea lacunosa L.) and hemp sesbania [Sesbania exaltata (Raf.) Rydb. ex A.W. Hill] presumably through increased crop competitiveness (Bennet and Shaw 2000) due to their ability to maintain vegetative growth longer (Nordby et al. 2002). Nevertheless, Rosenzweig and Tubiello (2007) suggested that under warmer climates, crops would tend to mature faster, resulting in less time available for carbohydrate accumulation and grain production. Responses to specific adaptation strategies for given cropping systems can still vary considerably, as a function of location and climate change scenario. Adapting longer maturing cultivars in a winter cereal production system requires enough precipitation over an extended growing season to sustain grain filling. If both warmer and drier conditions prevail, such an adaptation strategy is not applicable. On the contrary, the adaptation of fast growing species (i.e., those with high sink strength, hence positive response of photosynthesis) has the advantage of better competition for resources, thus faster adaptation to a changed climate.

\subsection{Nutrient uptake and utilization}

Nutrient utilization, mainly nitrogen, is an important factor for cultivar selection as an adaptive strategy but also as a crop competitiveness tool under various climate change scenarios. There is a general agreement that crop cultivars, particularly of cereals, can differ in their responsiveness to nitrogen (Gent and Kiyomoto 1998; Duan et al. 2007; Benin et al. 2012) possibly due to greater sink capacity, hence better nitrogen utilization or more extensive root systems (Lupton et al. 1974; Foulkes et al. 1994). Crop biomass is a component of two processes namely the amount of accumulated intercepted radiation and radiation use efficiency (Monteith 1977; Gallagher and Biscoe 1978). Foulkes et al. (1994) stated that maximum growth depends on the acquisition of sufficient nitrogen to form a canopy of sufficient size to intercept the majority of the incident radiation when adequate moisture to balance evaporation from the canopy is provided. One of the main traits conferring resistance to drought in winter wheat is the flowering date (Foulkes et al. 1997). More particularly, cultivars with early flowering are less prone to drought effects due to shorter life cycle they exhibit. Susceptible cultivars to dry conditions, especially toward the end to the growing season, uptake and utilize lower nitrogen. 
Hence, cultivars with efficient $\mathrm{N}$ uptake and utilization that exhibit drought resistance characteristics can be used for weed suppression and also as adaptive tools in less fertile or dry soils.

\subsection{Heat tolerance-improvements and expectations}

Improvements of heat-stress-tolerant germplasm lines have resulted in the development of the Hoveyzeh rice cultivar from Khuzestan delta in south Iran which attains spikelet fertility at average day temperatures of $45{ }^{\circ} \mathrm{C}$ (Jennings et al. 1979). Despite the impressive achievements by plant breeding programs, efforts to generate heat-tolerant crops have not been very successful. This is mainly because abiotic stress tolerance in plants is quantitatively inherited, and it is found to be controlled by multiple genes/quantitative trait loci (Blum et al. 1988). Advances in agricultural biotechnology have been successful in developing heat tolerance transgenically under controlled conditions (Grover et al. 2013).

\subsection{A synthesis}

Breeding objectives should be reorientated toward a selection of traditional $\times$ modern crop characteristics that will result in increased weed-suppressive ability (Dingkuhn et al. 2010), an ability to thrive in harsh environments and high yielding potential (Jones et al. 1997; Johnson et al. 1998). Hybrids of Oryza glaberrima $\times$ Oryza sativa share common parental characteristics such as weed competitiveness, ability to grow under stressful conditions without jeopardizing their yield (Jones et al. 1997; Johnson et al. 1998).

Priority should be focused on crop traits suitable for climate change scenarios for several reasons. This is true considering the detrimental effects of increased temperature
Table 8 Response of crop plants and weeds under elevated $\mathrm{CO}_{2}$, increased temperature, and prolonged drought periods
Climate change component

\begin{tabular}{|c|c|c|c|c|c|}
\hline & Plant response & Result & $\mathrm{CO}_{2}{ }^{\mathrm{a}}$ & Temperature & Drought \\
\hline \multirow[t]{14}{*}{ Crop plants } & Root mass & Root/shoot ratio & + & & \\
\hline & Leaf area & Interception of PAR & + & & \\
\hline & Leaf development & Leaf area & & - & \\
\hline & Flowering & Vegetative stage & & - & \\
\hline & Harvesting & Yield & & - & - \\
\hline & Fruit production & Yield & & - & \\
\hline & Vernalization & Vegetative stage & & - & \\
\hline & Stomata conductance & Rate of photosynthesis & & - & - \\
\hline & Stomata closure & WUE & & + & + \\
\hline & $\mathrm{CO}_{2} / \mathrm{O}_{2}$ & Rate of photosynthesis & & & - \\
\hline & Respiration rate & Biomass production & & + & \\
\hline & Seed formation period & Yield & & - & \\
\hline & Biomass production & Yield & + & - & - \\
\hline & Node number & Biomass, height & & & - \\
\hline \multirow[t]{9}{*}{ Weeds } & Stomata closure & WUE & + & & \\
\hline & Maturity rate & Vegetative stage & + & & \\
\hline & Root biomass & Root/shoot ratio & + & & \\
\hline & Distribution & & & + & \\
\hline & Vernalization & Vegetative stage & & - & \\
\hline & Biomass & & & + & \\
\hline & Seed germination $^{\mathrm{b}}$ & Distribution & & + & \\
\hline & Rhizomes $^{\mathrm{b}}$ & Distribution & & + & \\
\hline & Seed longevity & & & & + \\
\hline
\end{tabular}

+ and - signs indicate a positive and negative effect, respectively

$P A R$ photosynthetically active radiation

${ }^{\text {a }}$ Elevated $\mathrm{CO}_{2}$ favors, in most cases, $\mathrm{C} 3$ plant types

${ }^{\mathrm{b}}$ Seed germination and rhizome production, for most weed species, are affected negatively by low temperatures as it is mentioned in the text. Therefore, it is assumed that under relatively elevated temperatures, they will be affected positively 
or extended drought periods on crop yields, for example, in combination with the enhanced plasticity and adaptation ability the weed species respond to various environment changes. If an appropriate trait for climate change adaptation favors the weed-suppressive ability of the crop plant, then its selection should be prioritized. Table 8 , in an attempt to facilitate the selection process, summarizes the major responses of both crop plants and weeds under various scenarios of climate change.

As mentioned earlier, increased temperatures will reduce vernalization (i.e., the promotion of flowering in response to a prolonged exposure to low temperatures) requirements for both crops and weeds, particularly grasses. This in turn will shorten the vegetative period due to early reproductive induction (Chauvel et al. 2002), at the vegetative points, of the apex (Chouard 1960; Chauvel et al. 2002) which will result in biomass reductions and, in case of the crop, consequent yield reductions. As it was stated previously, increases in biomass production or its components, e.g., leaf area, tillers, stem weight, etc., are positively related to increased competitiveness for both crop plants and weeds as in the case of cereals, particularly winter wheat, and blackgrass [Alopecurus myosuroides Huds.] (Chauvel et al. 2002). Therefore, crop plants that maintain their vernalization periods, under abiotic stresses, unaffected will preserve appropriate vegetative periods for acceptable biomass production and yield but will also retain their suppressive ability against weeds.

In summary:

- The development of tolerant cultivars to drought with increased root/shoot ratio will result in enhanced water and nutrient uptake, unaffected growth rates and biomass production, hence improved weed-suppressing ability.

- Traits related with the maturity of cultivars is another option that merits further consideration for developing cultivars tolerant to drought and enhanced suppressive ability against weeds.

- Traits associated with the regulation of node formation and/or internode distance, particularly under drought stress conditions, can be used for developing high yielding and competitive cultivars against weeds.

- Traits or plant attributes related with harvest index variations such as those of infertile tillers and leaf area as mentioned above merit further investigation since they can influence both yield production through increased utilization of resources (i.e., PAR) and weed-suppressive ability (e.g., shading).

- Cultivars that exhibit allelopathic attributes should be prioritized in breeding programs.

- Cultivars that retain appropriate vernalization periods under increased temperatures, hence preserving the normal duration of vegetative growth stages, can reserve high yield production but also to exhibit suppressive ability against weeds.

\section{Conclusions}

Climate change is predicted to affect agricultural production in many ways. Climate change is likely to affect the growth of both crops and weeds, sometimes benefiting the crop sometimes the weeds. Crop yield in many areas will decrease due to increased temperatures or extended drought periods, whereas weed competition, despite the technological advances, will increase further crop yield reductions. A dual adaptive approach is needed not only to counteract the negative effects of climate change but also to enhance crop competitiveness against weeds. As it has been shown in this paper, cultivar selection serves this adaptive approach adequately. Cultivars with $\mathrm{C} 3$ photosynthetic pathway are more suitable for adaptation to elevated $\mathrm{CO}_{2}$ but also to compete with weeds, particularly those with $\mathrm{C} 4$ photosynthetic pathway. In addition, cultivars with mechanisms to resist drought through increases in root/shoot ratio will gain a significant advantage under dry conditions in marginal areas. The potential of these cultivars for weed suppression will more likely enhance, due to their ability to acquire water and nutrients effectively. However, increased temperatures, accompanied by extended drought periods, favor the selection of cultivars with longer maturity period which have also proven to be highly competitive by maintaining longer vegetative growth. Cultivars with allelopathic abilities should be used in integrated weed management systems since they have shown great potential for high yield production but also increased weedsuppressing ability. This paper investigates the complex interactions between crops and weeds under various climate change scenarios aiming to facilitate decision-making processes toward sustainable crop production systems. Developing cultivars to tolerate climate changes such as drought, temperature increases, or nutrient shortage can reduce fertilizer and irrigation inputs considerably. The incorporation of cultivars with enhanced weed suppression ability into the system can reduce herbicide inputs substantially (Callaway 1992; Gealy et al. 2003, 2014; Korres et al. 2008; Travlos 2012). This is even more demanding considering the increase of weed herbicide resistance evolution (Heap 2015). The cumulative effects from selecting a suitable S-C cultivar will be reflected in the reductions of environmental pollution, lower production costs, and sustainable food production. It is therefore imperative to expand research efforts to investigate how crop-weed interference under various abiotic stresses and cropping systems influences cultivar performance and subsequent yield outcome. This information could be incorporated into breeding programs for improving performance of cultivars under abiotic (climate change) and biotic (weed competition) stresses without compromising final yield. 


\section{References}

Aarssen LW (1989) Competitive ability and species coexistence: a 'plant's eye' view. Oikos 56:386-401. doi:10.2307/3565625

Adams RM, Hurd BH, Lenhart S, Leary N (1998) Effects of global climate change on agriculture: an interpretative review. Clim Res 11:19-30. doi:10.3354/cr011019

Adger WN, Kelly PM, Winkels A, Huy LQ, Locke C (2002) Migration, remittances, livelihood and trajectories and social resilience in Vietnam. Ambio 31:358-366. doi:10.1579/0044-7447-31.4.358

Ainsworth EA, Long SP (2005) What have we learned from 15 years of free-air $\mathrm{CO}_{2}$ enrichment (FACE)? A meta-analytic review of the responses of photosynthesis, canopy properties and plant production to rising $\mathrm{CO}_{2}$. New Phytol 165(2):351-372. doi:10.1111/j.14698137.2004.01224.x

Albert KR, Ro-Poulsen H, Mikkelsen TN, Michelsen A, van der Linden $\mathrm{L}$, Beier C (2011) Interactive effects of elevated $\mathrm{CO}_{2}$, warming, and drought on photosynthesis of Deschampsia flexuosa in a temperate heath ecosystem. J Exp Bot 62:4253-4266. doi:10.1093/jxb/err133

Alberto A, Ziska L, Cervancia C, Manalo P (1996) The influence of increasing carbon dioxide and temperature on competitive interactions between a $\mathrm{C} 3$ crop, rice (Oryza sativa) and a $\mathrm{C} 4$ weed (Echinochloa glabrescens). Funct Plant Biol 23(6):795-802. doi: 10.107/PP9960795

Andrews IKS, Storkey J, Sparkes DL (2015) A review of the potential for competitive cereal cultivars as a tool in integrated weed management. Weed Res 55:239-248. doi:10.1111/wre.12137

Anonymous (2001) Sida spinosa. European and Mediterranean Plant Protection Organization. 02/9188, Point 7.8

Anonymous (2008) Climate change impacts on pest animals and weeds. Communicating climate change. Module 13. Australian Government, Department of Agriculture, Fisheries and Forestry. Bureau of Meteorology

Anonymous (2013) Climate change consortium for specialty crops: impacts and strategies for resilience. California Dept. of Food and Agriculture, $64 \mathrm{p}$

Asfaw S, Lipper L (2011) Economics of PGRFA management for adaptation to climate change: a review of selected literature. Background study paper No 60. Commission on Genetic Resources for Food and Agriculture. Agricultural Economic Development Division (ESA), FAO, Rome, Italy

Assefa Y, Staggenborg SA, Prasad VPV (2010) Grain sorghum water requirement and responses to drought stress: a review. Crop Manag 9:1. doi:10.1094/CM-2010-1109-01-RV

Baldocchi D, Wong S (2008) Accumulated winter chill is decreasing in the fruit growing regions of California. Clim Chang 87(1):153-166. doi:10.1007/s10584-007-9367-8

Barrow JR, Lucero ME, Reyes-Vera I, Havstad KM (2008) Do symbiotic microbes have a role in plant evolution, performance and response to stress? Commun Integr Biol 1:69-73. doi:10.4161/cib.1.1.6238

Bazzaz FA, Carlson MR (1984) The response of plants to elevated $\mathrm{CO}_{2}$. I. Competition among the assemblage of annuals at two levels of soil moisture. Oecologia 62:196-198

Bello IA, Owen MDK, Hatterman-Valenti HM (1995) Effect of shade on velvetleaf (Abutilon theophrasti) growth, seed production, and dormancy. Weed Technol 9:452-455

Benaragama D, Rossnagel DB, Shirtliffe SJ (2014) Breeding for competitive and high-yielding crop cultivars. Crop Sci 54:1015-1025. doi: 10.1614/WS-D-10-00121.1

Benin G, Bornhofen E, Beche E, Pagliosa ES, da Silva CL, Pinnow C (2012) Agronomic performance of wheat cultivars in response to nitrogen fertilization levels. Acta Scientiarum Agronomy 34(3): 275-283. doi:10.4025/actasciagron.v34i3.14468

Bennett AC, Shaw DR (2000) Effect of Glycine max cultivars and weed control weed seed characteristic. Weed Sci 48:431-435
Benvenuti M, Steffani A (1994) Effects of shade on reproduction and some morphological characteristics of Abutilon theophrasti Medicus, Datura stramonium L. and Sorghum halepense L. Pers. Weed Res 34:283-288. doi:10.1111/j.1365-3180.1994.tb01996.x

Bertholdsson NO (2005) Early vigour and allelopathy - two useful traits for enhanced barley and wheat competitiveness against weeds. Weed Res 45:94-102. doi:10.1111/j.1365-3180.2004.00442.x

Bertholdsson NO (2007) Varietal variation in allelopathic activity in wheat and barley and possibilities for use in plant breeding. Allelopathy J 19:1. ISSN: 0971-4693

Bertholdsson NO (2010) Breeding spring wheat for improved allelopathic potential. Weed Res 50:49-57. doi:10.1111/j.1365-3180.2009. 00754. $\mathrm{x}$

Bertholdsson NO (2011) Use of multivariate statistics to separate allelopathic and competitive factors influencing weed suppression ability in winter wheat. Weed Res 51:273-283. doi:10.1111/j.1365-3180. 2011.00844.x

Bertholdsson NO, Andersson SC, Merker A (2012) Allelopathic potential of Triticum spp., Secale spp. and Triticosecale spp. and use of chromosome substitutions and translocations to improve weed suppression ability in winter wheat. Plant Breed 131:75-80. doi:10.1111/j. 1439-0523.2011.01895.x

Blum A (1996) Crop responses to drought and the interpretation of adaptation. Plant Growth Regul 20:135-148. doi:10.1007/ BF00024010

Blum A, Mayer J, Golan G (1988) The effect of grain number (sink size) on source activity and its water-relations in wheat. J Exp Bot 39: $106-114$

Bodner G, Nakhforoosh, Kaul HP (2015) Management of crop water under drought: a review. Agron Sustain Dev 35:401-442. doi:10. 1007/s13593-015-0283-4

Bruhn D, Mikkelsen TN, Pilegaard K, Gavito ME, Saxe H (2001) Climate change in a plant ecophysiological perspective. In: Jorgensen AMK, Fenger J, Halsnaes K (eds) Climate change research. Danish contributions. Danish Meteorological Institute/Gads Forlag, Copenhagen, pp 167-190

Brunce JA, Ziska LH (2000) Crop ecosystems responses to climatic change. Crop/weed interactions. In: Reddy KR, Hodges HF (eds) Climate change and global crop productivity. Cab International, Wallingford, pp 333-348. ISBN 978-0851994390

Bunce JA (1998) Effects of humidity on short-term responses of stomatal conductance to an increase in carbon dioxide concentration. Plant Cell Environ 21:115-120. doi:10.1046/j.1365-3040.1998.00253.x

Callaway MB (1992) A compendium of crop varietal tolerance to weeds. Am J Altern Agr 7:169-180. doi:10.1017/S088918930000477X

Campbell BD, Stafford Smith DM, McKeon GM (1997) Elevated $\mathrm{CO}_{2}$ and water supply interactions in grasslands: a pastures and rangelands management perspective. Glob Chang Biol 3:177-187. doi:10.1046/j.1365-2486.1997.00095.x

Carter DR, Peterson KM (1983) Effects of $\mathrm{CO}_{2}$ enriched atmosphere on the growth and competitive interaction of a $\mathrm{C} 3$ and $\mathrm{C} 4$ grass. Oecologia 58:188-193. doi:10.1007/BF00399215

Cerqueira FB, Erasmo EAL, Silva JIC, Nunes TV, Carvalho GP, Silva AA (2013) Competition between drought-tolerant upland rice cultivars and weeds under water stress condition. Planta Daninha 31(2): 291-302. doi:10.1590/S0100-83582013000200006

Chandrasena N (2009) How will weed management change under climate change? Some perspectives. J Crop Weed 5(2):95-105

Chauhan BS, Abugho SB (2013) Effect of water stress on the growth and development of Amaranthus spinosus, Leptochloa chinensis, and rice. Am J of Plant Sci 4:989-998. doi:10.4236/ ajps.2013.45122

Chauvel B, Munier-Jolain NM, Grandgirard D, Gueritaine G (2002) Effect of vernalization on the development and growth of Alopecurus myosuroides. Weed Res 42:166-175 
Chen XH, Hu F, Kong CH (2008) Varietal improvement in rice allelopathy. Allelopathy J 22:379-384

Chijioke OB, Haile M, Waschkeit C (2011) Implication of climate change on crop yield and food accessibility in Sub Saharan Africa. Interdisciplinary term paper, University of Bonn, Germany. Global Climate Adaptation Partnership (GCAP) (2012). Projects and Clients. http://www.climateadaptation.cc/projects-clients. Accessed 18 Sept 2015

Chouard P (1960) Vernalization and its relations to dormancy. Annu Rev Plant Physiol 11:191-238

Ciais P, Reichstein M, Viovy N, Granier A, Ogee J, Allard V, Aubinet M, Buchmann N, Bernhofer C, Carrara A, Chevallier F, De Noblet N, Friend AD, Friedlingstein P, Grunwald T, Heinesch B, Keronen P, Knohl A, Krinner G, Loustau D, Manca G, Matteucci G, Miglietta F, Ourcival JM, Papale D, Pilegaard K, Rambal S, Seufert G, Soussana JF, Sanz MJ, Schulze ED, Vesala T, Valentini R (2005) Europe-wide reduction in primary productivity caused by the heat and drought in 2003. Nature 437:529-533. doi:10.1038/nature03972

Cline WR (1992) The economics of global warming. Washington, DC: Peterson Institute for International Economics. ISBN: 978-0-88132$132-6$

Coakley SM, Scherm H, Chakraborty S (1999) Climate change and plant disease management. Annu Rev Phytopathol 37:399-426. doi:10. 1146/annurev.phyto.37.1.399

Cohen S, Wheaton E, Masterton J (1992) Impacts of climatic change scenarios in the Prairie Provinces: a case study from Canada. SRC Publication No. E-2900-4-D-92, Saskatchewan Research Council, Saskatoon, Canada, $157 \mathrm{p}$

Connor DJ, Wang YP (1993) Climatic change and the Australian wheat crop. In Proceedings of the Third Symposium on the Impact of Climatic Change on Agricultural Production in the Pacific Rim, Taipei, Taiwan, ROC, pp. 29-47

Cousens RD, Mokhtari S (1998) Seasonal and site variability in the tolerance of wheat cultivars to interference from Lolium rigidum. Weed Res 38:301-307. doi:10.1046/j.1365-3180.1998.00097.x

Curtis PS, Wang XA (1998) Meta-analysis of elevated CO2 effects on woody plant mass, form, and physiology. Oecologia 113:299-313. doi:10.1023/A:1020305006949

Darwin R, Kennedy D (2000) Economic effects of $\mathrm{CO}_{2}$ fertilization of crops: transforming changes in yield into changes in supply. Environ Mod Assess 5:157-168. doi:10.1023/A:1019013712133

Daudenmire R (1970) Steppe vegetation of Washington. Washington Agric. Exp. Stm. Bull. No. 62

DeCeault MT, Polito VS (2008) High temperatures during bloom can inhibit pollen germination and tube growth, and adversely affect fruit set in the Prunus Domestica cultivars "improved French" and "Muir Beauty". In Proceedings of IX International Symposium on Plum and Prune Genetics, Breeding and Pomology, March 16-19, 2008, Dipartimento Colture Arboree, University of Palermo, Italy, $874 \mathrm{p}$

DeFelice MS, Witt WW, Barrett M (1988) Velvetleaf (Abutilon theophrasti) growth and development in conventional and no-till corn (Zea mays). Weed Sci 36:609-615

Didon UME, Bostrom U (2003) Growth and development of six barley (Hordeum vulgare ssp. vulgare L.) cultivars in response to a model weed (Sinapis alba L.). J Agron Crop Sci 189:409-417. doi:10. 1046/j.0931-2250.2003.00065.x

Dijkstra FA, Pendall E, Mosier AR, King JY, Milchunas DG, Morgan JA (2008) Long-term enhancement of $\mathrm{N}$ availability and plant growth under elevated $\mathrm{CO}_{2}$ in a semi-arid grassland. Funct Ecol 22:975982. doi:10.1111/j.1365-2435.2008.01398.x

Dingkuhn M, Singh BB, Clerget B, Chantereau J, Sultan B (2010) Past, present and future criteria to breed crops for water-limited environments in West Africa. In Proceedings of the 4th International Crop Science Congress "New directions for a diverse planet", 26 September-1 October 2004, Brisbane, Australia
Drake BG, Gonzalez-Meler MA, Long SP (1997) More efficient plants: a consequence of rising atmospheric $\mathrm{CO}_{2}$ ? Annu Rev Plant Physiol Plant Mol Biol 48:609-639. doi:10.1146/annurev.arplant.48.1.609

Duan YH, Zhang YL, Ye LT, Fan XR, Xu GH, Shen QR (2007) Responses of rice cultivars with different nitrogen use efficiency to partial nitrate nutrition. Ann Bot 99:1153-1160. doi:10.1093/aob/ mem051

Dukes JS, Mooney HA (1999) Does global change increase the success of biological invaders? Trends Ecol Evol 14(4):135-139

Dukes JS, Pontius J, Orwig D, Garnas JR, Rodgers VL, Brazee N, Cooke B, Theoharides KA, Stange EE, Harrington R, Ehrenfeld J, Gurevitch J, Lerdau M, Stinson K, Wick R, Ayres M (2009) Responses of insect pests, pathogens, and invasive plant species to climate change in the forests of northeastern North America: what can we predict? Can J For Res 39:231-248. doi:10.1139/X08-171

Edwards GE, Huber S (1981) The C4 pathway. In: Hatch MD, Boardman NK (eds) The biochemistry of plants. Academic, New York, pp 238-281. ISBN 012675408X

Ehleringer J (1983) Ecophysiology of Amaranthus palmeri, a Sonoran Desert summer annual. Oecologia 57:107-112. doi:10.1007/ BF00379568

Erbs M, Manderscheid R, Jansen G, Seddig S, Pacholski A, Weigel HJ (2010) Effects of free-air $\mathrm{CO}_{2}$ enrichment and nitrogen supply on grain quality parameters and elemental composition of wheat and barley grown in crop rotation. Agric Ecosyst Environ 136:59-68. doi:10.1016/j.agee.2009.11.009

Evans RO, Skagss RW, Sneed RE (1991) Stress day index models to predict corn and soybean relative yield under high water table conditions. Trans ASAE 5, 1997-2005. doi:0001-2351/91/3405-1997

Fargione J, Tilman D (2006) Plant species traits and capacity for resource reduction predict yield and abundance under competition in nitrogen-limited grassland. Funct Ecol 20:533-540. doi:10.1111/j. 1365-2435.2006.01116.x

Foulkes MJ, Scott RK, Sylvester-Bradley R, Clare RW, Evans EJ, Frost DL, Kettlewell PS, Ramsbottom JE, White E (1994) Suitabilities of UK winter wheat (Triticum aestivum L.) varieties to soil and husbandry conditions. Plant Varieties Seeds 7:161-181

Foulkes MJ, Scott PK, Sylvester-Bradley R (1997) Optimising winter wheat varietal selection on drought-prone soil types. In optimising cereal inputs: its scientific basis. Asp Appl Biol 50:61-77

Fuhrer J (2003) Agroecosystem responses to combinations of elevated $\mathrm{CO}_{2}$, ozone, and global climate change. Agric Ecosyst Environ 97: 1-20. doi:10.1016/S0167-8809(03)00125-7

Gala Bijl C, Fisher M (2011) Crop adaptation to climate change. CSA News Magazine July 2011, 5-9

Gallagher JN, Biscoe PV (1978) Radiation absorption, growth and yield of cereals. J Agric Sci. 91:47-60. doi:10.1017/S0021859600056616

Gealy DR, Moldenhauer KAK (2012) Use of 13C isotope discrimination analysis to quantify distribution of barnyardgrass and rice roots in a four-year study of weed suppressive rice. Weed Sci 60:133-142. doi:10.1614/WS-D-10-00145.1

Gealy DR, Yan W (2012) Weed suppression potential of 'Rondo' and other indica rice germplasm lines. Weed Technol 26:517-524. doi: 10.1614/WT-D-11-00141.1

Gealy DR, Wailes EJ, Estorninos LE Jr, Chavez RSC (2003) Rice cultivar differences in suppression of barnyardgrass (Echinochloa crusgalli) and economics of reduced propanil rates. Weed Sci 51:601609. doi:10.1614/0043-1745(2003)051[0601:RCDISO]2.0.CO;2

Gealy DR, Moldenhauer KA, Duke S (2013a) Root distribution and potential interactions between allelopathic rice, sprangletop (Leptochloa spp.), and barnyardgrass (Echinochloa crus-galli) based on $13 \mathrm{C}$ isotope discrimination analysis. J Chem Ecol 39: 186-203. doi:10.1007/s10886-013-0246-7

Gealy DR, Moldenhauer KA, Jia MH (2013b) Field performance of STG06L-35-061, a new genetic resource developed from crosses between weed-suppressive indica rice and commercial southern 
U.S. long-grains. Plant Soil 370:277-293. doi:10.1007/s11104-013$1587-2$

Gealy DR, Anders M, Watkins B, Duke S (2014) Crop performance and weed suppression by weed-suppressive rice cultivars in furrow- and flood-irrigated systems under reduced herbicide inputs. Weed Sci 62:303-320. doi:10.1614/WS-D-13-00104.1

Gent MPN, Kiyomoto RK (1998) Physiological and agronomic consequences of Rht genes in wheat. In: Basra AS (ed) Crop science: recent advances, pp 27-46

Ghannoum O (2009) C4 photosynthesis and water stress. Ann Bot 103: 635-644. doi:10.1093/aob/mcn093

Gibson KD, Fischer AJ, Foin TC, Hill JE (2003) Crop traits related to weed suppression in water-seeded rice (Oryza sativa L.). Weed Sci 51:87-93. doi:10.1614/0043-1745(2003)051[0087:CTRTWS]2.0. $\mathrm{CO} ; 2$

Glover J, Johnson H, Lizzio J, Wesley V, Hattersley P, Knight C (2008) Australia's crops and pastures in a changing climate - can biotechnology help? Australian Government Bureau of Rural Sciences, Canberra

Goldwasser Y, Lanini WT, Wrobel RL (2001) Tolerance of tomato varieties to Lespedeza dodder. Weed Sci 49:520-523. doi:10.1614/ 0043-1745(2001)049[0520:TOTVTL]2.0.CO;2

Gouache D, Le Bris X, Bogard M, Deudon O, Page C, Gate P (2012) Evaluating agronomic adaptation options to increasing heat stress under climate change during wheat grain filling in France. Eur J Agron 39:62-70. doi:10.1016/j.eja.2012.01.009

Gregory PJ, Ingram JS, Brklacich M (2005) Climate change and food security. Phil Trans R Soc B 360:2139-2148. doi:10.1098/rstb. 2005.174

Griffin JG, Thomas GR, Mason-Pharr D (2004) Heat and drought influence photosynthesis, water relations, and soluble carbohydrates of two ecotypes of redbud (Cercis Canadensis). J Am Soc Hort Sci 129(4):497-502

Grime JP (1979) Evidence for the strategies in plants and relevance to ecological and evolutionary theory. Am Natur 111:1169-1192

Grover A, Mittal D, Negi M, Lavania D (2013) Generating high temperature tolerant transgenic plants: achievements and challenges. Plant Sci 205-206:38-47. doi:10.1016/j.plantsci.2013.01.005

Grzesiak MT, Marcinska I, Janowiak F, Rzepka A, Hura T (2012) The relationship between seedling growth and grain yield under drought conditions in and triticale genotypes. Acta Physiol Plant 34:17571764. doi:10.1007/s11738-012-0973-3

Halvorson WL, Guertin P (2003) Factsheet for Ipomoea purpurea (L.) Roth. USGS weeds in the west project: status of introduced plants in Southern Arizona parks. U.S. Geological Survey, Southwest Biological Science Center and University of Arizona

Hamayun M, Sohn EY, Khan SA, Shinwari ZK, Khan AL, Lee IJ (2010) Silicon alleviates the adverse effects of salinity and drought stress on growth and endogenous plant growth hormones of soybean (Glycine $\max$ L.). Pak J Bot 42:1713-1722. doi:10.1007/s00344-012-9274-8

Hardin G (1960) The competitive exclusion principle. Science 131(3409):1292-1297

Hay JL, Walker AJ (1992) An introduction to the physiology of crop yield. Longman Scientific and Technical and John Wiley and Sons Publications, pp. 163-168. ISBN: 978-0582408081

Heap I (2015) The international survey of herbicide resistant weeds. Online Internet. www.weedscience.org. Accessed 12 Nov 2015

Hulme M (1996) Global warming. Prog Phys Geogr 20:216-223

Hulme M, Wigley T, Jiang T, Zhao Z, Wang F, Ding Y, Leemans R, Markham A (1992) Climate change due to the greenhouse effect and its implications for China. CRU/WWF/SMA, World Wide Fund for Nature, Gland, Switzerland

IPCC (2001) Impacts, adaptation and vulnerability. Contribution of the Working Group II to the Third Assessment Report on the Intergovernmental Panel on Climate Change. UK: Cambridge University Press. ISBN: 978-0521015004
IPCC (2007) Climate change 2007: the physical science basis. In: Solomon S, Qin D, Manning M, Chen Z, Marquis M, Averyt KB, Tignor M, Miller HL (eds) Contribution of Working Group I to the Fourth Assessment Report of the Intergovernmental Panel on Climate Change, Cambridge, UK/New York, NY: Cambridge University Press

IPCC (2014) Climate change 2014: impacts, adaptation, and vulnerability. Part A: global and sectoral aspects. In: Field CB, Barros VR, Dokken DJ, Mach KJ, Mastrandrea MD, Bilir TE, Chatterjee M, Ebi KL, Estrada YO, Genova RC, Girma B, Kissel ES, Levy AN, MacCracken S, Mastrandrea PR, White LL (eds) Contribution of Working Group II to the Fifth Assessment Report of the Intergovernmental Panel on Climate Change. Cambridge University Press, Cambridge, United Kingdom and New York, NY, USA, $1132 \mathrm{p}$

Jennings PR, Coffman WR, Kauffman HE (1979) Rice improvement. IRRI, Los Banos, $186 \mathrm{p}$

Johnson D, California Invasive Plant Council (2013) Invasive plants, climate change and agriculture, presented at the California Department of Food and Agriculture Climate Change Adaptation Consortium, March 20, American Canyon, CA

Johnson DE, Dingkuhn M, Jones MP, Mahamane MC (1998) The influence of rice plant type on the effect of weed competition on $O$. sativa and $O$. glaberrima. Weed Res 38:207-216. doi:10.1046/j.13653180.1998.00092.x

Jones MP, Dingkuhn M, Aluko GK, Semon M (1997) Interspecific $O$. sativa L. $\times O$. glaberrima Steud. progenies in upland rice improvement. Euphytica 92:237-246. doi:10.1023/A:1002969932224

Juskiw PE, Helm JH, Salmon DF (2000) Competitive ability in mixtures of small grain cereals. Crop Sci 40:159-164. doi:10.2135/ cropsci2000.401159x

Karl TR, Melillo JM, Peterson TC (eds) (2009) Global climate change impacts in the United States. A state of knowledge report from the U.S. Global Change Research Program. Cambridge University Press, New York, USA, 196 p. ISBN: 978-0-521-14407-0

Kasperbauer MJ, Karlen DL (1994) Plant spacing and reflected far-red light effects on phytochrome-regulated photosynthate allocation in corn seedlings. Crop Sci 34:1564-1569

Kawano K, Jennings PR (1983) Tropical crop breeding — achievements and challenges. In IRRI, Potential productivity of field crops under different environments, Los Banos, Laguna, Philippines

Khodarahmpour Z (2011) Effect of drought stress induced by polyethylene glycol (PEG) on germination indices in corn (Zea mays L.) hybrids. Afr J Biotechnol 10:18222-18227

King LJ (1966) Weeds of the world - biology and control. Interscience, New York, 270 p. ISBN: 112596779X

Kong CH, Hu F, Wang P, Wu JL (2008) Effect of allelopathic rice varieties combined with cultural management options on paddy field weeds. Pest Manag Sci 64:276-282. doi:10.1002/ps.1521

Kong CH, Chen XH, Hu F, Zhang SZ (2011) Breeding of commercially acceptable allelopathic rice cultivars in China. Pest Manag Sci 67: 1100-1106. doi:10.1002/ps.2154

Korres NE (2000) The effects of seed rate and varietal selection for weed suppression and herbicide sensitivity in winter wheat (Triticum aestivum $\mathrm{L}$.). $\mathrm{PhD}$ thesis, Reading University, Reading University, UK

Korres NE (2005) Encyclopaedic dictionary of weed science. Theory and digest, Intercept and Lavoisier (pubs). Andover, Paris, 695 p. ISBN: 1-898298-99-8

Korres NE, Froud-Williams RJ (2002) Effects of winter wheat cultivars and seed rate on the biological characteristics of naturally occurring weed flora. Weed Res 42:417-428. doi:10.1046/j.1365-3180.2002. 00302. $\mathrm{x}$

Korres NE, Froud-Williams RJ (2004) The interrelationships of winter wheat cultivars, crop density and competition of naturally occurring 
weed flora. Biol Agric Hortic 22(1):1-20. doi:10.1080/01448765. 2004.9754984

Korres NE, Norsworthy JK (2015) Influence of Palmer amaranth interrow distance and emergence date on seed production in wide-row and drill-seeded soybean. In: Proceedings of the Weed Science Society of America, Annual Meeting, Lexington, Kentucky, USA, February 9-12, 2015

Korres NE, Froud-Williams RJ, Chachalis D, Pavli O, Skaracis GN (2008) Yielding ability and competitiveness of wheat cultivars against weeds, 4th EPSO Conference: Plants for Life, Toulon (Cote d' Azur), France, 22-26 June 2008, pp. 52

Korres NE, Norsworthy JK, Bagavathiannan MV, Mauromoustakos A (2015) Distribution of arable weed populations along eastern Arkansas Mississippi Delta roadsides: factors affecting weed occurrence. Weed Technol. doi:10.1614/WT-D-14-00152.1

Kramer PJ (1983) Water deficits and plant growth. In: Kramer PJ (ed) Water relations of plants. Academic, New York, pp 342-389. ISBN 978-0124250406

Larson C (2013) Losing arable land, China faces stark choice: adapt or go hungry. Science 339:644-645. doi:10.1126/science.339.6120.644

Larsson S, Gorny AG (1988) Grain yield and drought resistance indices of oat cultivars in field rain shelter and laboratory experiments. J Agron Crop Sci 161:277-286. doi:10.1111/j.1439-037X.1988. tb00668.x

Le Houerou HN (1996) Climate changes, drought and desertification. J Arid Environ 34:133-185. doi:10.1006/jare.1996.0099

Leakey ADB, Ainsworth EA, Bernacchi CJ, Rogers A, Long SP, Ort DR (2009) Elevated $\mathrm{CO}_{2}$ effects on plant carbon, nitrogen and water relations: six important lessons from FACE. J Exp Bot 60:28592876. doi:10.1093/jxb/erp096

Leguizamon ES, Yanniccari ME, Guiamet JJ, Acciaresi HA (2011) Growth, gas exchange and competitive ability of Sorghum halepense populations under different soil water availability. Can J Plant Sci 91:1011-1025. doi:10.4141/cjps10202

Lemerle D, Verbeek B, Orchard B (2001) Ranking the ability of wheat varieties to compete with Lolium rigidum. Weed Res 41:197-209. doi:10.1046/j.1365-3180.2001.00232.x

Lobell DB, Field CB (2011) California perennial crops in a changing climate. Clim Chang 109(1):317-333. doi:10.1007/s10584-0110303-6

Lobell DB, Ortiz-Monasterio JI, Asner GP, Matson PA, Naylor RL (2005) Analysis of wheat yield and climatic trends in Mexico. Field Crops Res 94:250-256. doi:10.1016/j.fcr.2005.01.007

Lobell DB, Field CB, Cahill KN, Bonfils C (2006) Impacts of future climate change on California perennial crop yields. Model projections with climate and crop uncertainties. Agric For Meteorol 141(2-4):208-218. doi:10.1016/j.agrformet.2006.10.006

Lupton FGH, Oliver RH, Ellis FB, Barnes BT, Howse KR, Welbank PJ, Taylor PJ (1974) Root and shoot growth of semi-dwarf and taller winter wheats. Ann Appl Biol 77:129-144. doi:10.1111/j.17447348.1974.tb06881.x

Ma HJ, Shin DH, Lee IJ, Koh JC, Park SK, Kim KU (2006) Allelopathic K21 selected as promising allelopathic rice. Weed Biol Manag 6: 189-196. doi:10.1111/j.1445-6664.2006.00219.x

Malik VS, Swanton CJ, Michaels TE (1993) Interaction of white bean (Phaseolus vulgaris L.) cultivars, row spacing, and seeding density with annual weeds. Weed Sci 41:62-68

Manea A, Leishman MR, Downey PO (2011) Exotic C4 grasses have increased tolerance to glyphosate under elevated carbon dioxide. Weed Sci 59:28-36. doi:10.1614/WS-D-10-00080.1

Mann GC (1980) Variety development. Proceedings of the 16 th NIAB Crop Conference, 7-15

Mason HE, Spaner D (2006) Competitive ability of wheat in conventional and organic management systems: a review of the literature. Can J Plant Sci 86:333-343. doi:10.4141/P05-051
Matthews RB, Kropff MJ, Bachelet D, van Laar HH (1994) The impact of global climate change on rice production in Asia: a simulation study. Report No. ERL-COR-821, U.S. Environmental Protection Agency, Environmental Research Laboratory, Corvallis, OR

Maun MA, Bennett SCH (1986) The biology of Canadian weeds. 77. Echinochloa crus-galli (L.) Beauv. Can J Plant Sci 66:739-759. doi:10.4141/cjps86-093

McGiffen ME Jr, Forcella F, Lindstrom MJ, Reicosky DC (1997) Covariance of cropping systems and foxtail density as predictors of weed interference. Weed Sci 45, 388-396. ISSN: 00431745

Mohammed AR, Tarpley L (2009) High nighttime temperatures affect rice productivity through altered pollen germination and spikelet fertility. Agric For Meteorol 149:999-1008. doi:10.1016/j. agrformet.2008.12.003

Mohler CL (2001) Enhancing the competitive ability of crops. In: Liebman M, Mohler CL, Staver CP (eds) Ecological management of agricultural weeds. Cambridge University Press, Cambridge, pp. 231-269. ISBN: 1139427245, 9781139427241

Monteith JL (1977) Climate and efficiency of crop production in Britain. Philos Trans R Soc Lond B 281:277-294. doi:10.1098/rstb.1977. 0140

Morison JIL (1989) Plant growth in increased atmospheric $\mathrm{CO}_{2}$. In: Fantechi R, Ghazi A (eds) Carbon dioxide and other greenhouse gases: climatic and associated impacts. Kluwer Academic, Dordrecht, pp 228-244. ISBN 0-7923-0191-9

Morison JIL (1993) Response of plants to CO2 under water limited conditions. Vegetatio 104/105:193-209. doi:10.1007/BF00048153

Naidu VSGR, Paroha S (2008) Growth and biomass partitioning in two weed species Parthenium hysterophorus $\left(\mathrm{C}_{3}\right)$ and Amaranthus viridis $\left(\mathrm{C}_{4}\right)$ under elevated $\mathrm{CO}_{2}$. Eco Env Cons 14(4):9-12

Newton PCD, Clark H, Bell CC, Glasgow EM (1996) Interaction of soil moisture and elevated $\mathrm{CO}_{2}$ on the above-ground growth rate, root length density and gas exchange of turves from temperate pasture. $\mathrm{J}$ Exp Bot 47(6):771-779. doi:10.1093/jxb/47.6.771

Nordby DE, Alderks DL, Nafziger ED (2002) Competitiveness with weeds of soybean cultivars with different maturity and canopy width characteristics. Weed Technol 21:1082-1088

Obirih-Opareh N, Adwoa Onumah J (2014) Climate change impact pathways on agricultural productivity in africa: a review. J Environ Earth Sci 4:4, 115-121. ISSN: 2224-3216

Oerke EC (2006) Crop losses to pests. J Agric Sci 144:31-43. doi:10. $1017 / \mathrm{S} 0021859605005708$

Olesen JE, Bindi M (2002) Consequences of climate change for European agricultural productivity, land use and policy. Eur J Agron 16:239-262. doi:10.1016/S1161-0301(02)00004-7

Olesen JE, Hansen PK, Berntsen J, Christensen S (2004) Simulation of above-ground suppression of competing species and competition tolerance in winter wheat varieties. Field Crops Res 89:263-280. doi:10.1016/j.fcr.2004.02.005

Osunsami S (2009) Killer pigweeds threaten crops in the South. http:// abcnews.go.com/WN/pig-weed-threatensagriculture-industryovertaking-fields-crops/story?id8766404. Accessed 5 May 2015

Pace PF, Crale HT, El-Halawany SHM, Cothren JT, Senseman SA (1999) Drought induced changes in shoot and root growth of young cotton plants. J Cotton Sci 3:183-187. doi:http://www.journal.cotton.org/ journal/1999-03/4/upload/jcs03-183.pdf

Paknejad F, Nasri M, Moghadam HRT, Zahedi H, Alahmadi MF (2007) Effects of drought stress on chlorophyll fluorescence parameters, chlorophyll content and grain yield of wheat cultivars. J Biol Sci 7, 841-847. doi:http://en.journals.sid.ir/ViewPaper.aspx?ID= 103989

Paolini R, Del Puglia S, Principi M, Barcellona O, Riccardi E (1998) Competition between safflower and weeds as influenced by crop genotype and sowing time. Weed Res 38:247-255. doi:10.1046/j. 1365-3180.1998.00096.x 
Parry ML (1990) Climate change and world agriculture. Earthscan Publications, London. doi:10.1080/00139157.1991.9931405

Patterson DT (1985) Comparative eco-physiology of weeds and crops. In: Duke SO (ed) Weed Physiology, vol. 1. CRC, Boca Raton, pp 101-129

Patterson DT (1995) Weeds in a changing climate. Weed Sci 43, 685701. ISSN: 00431745

Patterson DT, Flint EP, Beyers JL (1984) Effects of $\mathrm{CO}_{2}$ enrichment on competition between a $\mathrm{C} 4$ weed and a C3 crop. Weed Sci 32:1, 101105. ISSN: 00431745

Patterson DT, Westbrook JK, Joyce RJV, Lingren PD, Rogasik J (1999) Weeds, insects and diseases. Clim Chang 43:711-727. doi:10.1023/ A: 1005549400875

Peng S, Huang J, Sheehy JE, Laza RC, Visperas RM, Zhong X, Centeno GS, Khush GS, Cassman KG (2004) Rice yields decline with higher night temperature from global warming. PNAS 101(27):99719975. doi:10.1073/pnas.0403720101

Perez de Vida FB, Laca EA, Mackill DJ, Fernandez GM, Fischer AJ (2006) Relating rice traits to weed competitiveness and yield: a path analysis. Weed Sci 54:1122-1131. doi:10.1614/WS-06-042R.1

Peters K, Breitsameter L, Gerowitt B (2014) Impact of climate change on weeds in agriculture: a review. Agron Sustain Dev 34:707-721. doi: 10.1007/s13593-014-0245-2

Pheng S, Olofsdotter M, Jahn G, Nesbitt H, Adkins S (2009a) Potential allelopathic rice lines for weed management in Cambodian rice production. Weed Biol Manag 9:259-266. doi:10.1111/j.1445-6664. 2009.00349.x

Pheng S, Olofsdotter M, Jahn G, Adkins S (2009b) Allelopathic potential of Cambodian rice lines under field conditions. Weed Biol Manag 9: 267-275. doi:10.1111/j.1445-6664.2009.00350.x

Poorter H, Navas ML (2003) Plant growth and competition at elevated $\mathrm{CO}_{2}$ : on winners, losers and functional groups. New Phytol 157(2): 175-198. doi:10.1046/j.1469-8137.2003.00680.x

Pope KS (2012) Climate change adaptation: temperate perennial crops, presented at the California Department of Food and Agriculture Climate Change Adaptation Consortium, November 28, Modesto, CA

Pope KS, Dose V, Da Silva D, Brown PH, Leslie CA, DeJong TM (2013) Detecting nonlinear response of spring phenology to climate change by Bayesian analysis. Glob Chang Biol 19(5):1518-1525. doi:10. $1111 / \mathrm{gcb} .12130$

Porter JR, Semenov MA (2005) Crop responses to climatic variation. Philos Trans R Soc B: Biol Sci 360:2021-2035. doi:10.1098/rstb. 2005.1752

Prasad PVV, Boote KJ, Allen LH Jr (2006a) Adverse high temperature effects on pollen viability, seed-set, seed yield and harvest index of grain-sorghum (Sorghum bicolor L. Moench) are more severe at elevated carbon dioxide due to higher tissue temperatures. Agric For Meteorol 139(3-4):237-251. doi:10.1016/j.agrformet.2006.07. 003

Prasad PV, Boote KJ, Allen LH, Sheehy JE, Thomas JM (2006b) Species, ecotype and cultivar differences in spikelet fertility and harvest index of rice in response to high temperature stress. Field Crops Res 95:398-411. doi:10.1016/j.fcr.2005.04.008

Qaderi MM, Lynch AL, Godin VJ (2013) Single and interactive effects of temperature, carbon dioxide, and watering regime on the invasive weed black knapweed (Centaurea nigra). Ecoscience 20(4):328338. doi:10.2980/20-4-3631

Ragab AR, Abdel-Raheem AT, Kasem ZA, Omar FD, Samera AM (2007) Evaluation of R1 tomato somaclone plants selected under poly ethylene glycol (PEG) treatments. Afr Crop Sci Soc 8: 20172025. doi:http://www.acss.ws/upload/xml/research/468.pdf

Rajcan I, Swanton CJ (2001) Understanding weed competition: resource competition, light quality and the whole plant. Field Crops Res 71: 139-150. doi:10.1016/S0378-4290(01)00159-9
Riar DS, Norworthy JK, Steckel LE, Stephenson DO, Eubank TW, Scott RC (2013) Assessment of weed management practices and problem weeds in the midsouth United States - soybean: a consultant's perspective. Weed Technol 27:612-622. doi:10.1614/WT-D-12-00167.

Richards RA, Thurling N (1978) Variation between and within species of rapeseed (Brasica campestris and B napus) in response to drought stress. I. Sensitivity at different stages of development. Aust J Agric Res 29:469-477. doi:10.1071/AR9780469

Ripley BS, Gilbert ME, Ibrahim DG, Osborne CP (2007) Drought constraints on $\mathrm{C} 4$ photosynthesis: stomatal and metabolic limitations in $\mathrm{C} 3$ and C4 subspecies of Alloteropsis semialata. J Exp Bot 58: 1351-1363. doi:10.1093/jxb/erl302

Rosenzweig C, Tubiello FN (2007) Adaptation and mitigation strategies in agriculture: an analysis of potential synergies. Mitig Adapt Strat Glob Chang 12:855-873. doi:10.1007/s11027-007-9103-8

Royo C, Abaza M, Bianco R, Moral LFG (2000) Triticale grain growth and morphometry as affected by drought stress, late sowing and simulated drought stress. Aust J Physiol 27:1051-1059. doi:10. 1071/PP99113

Sakthivelu G, Devi MKA, Giridhar P, Rajasekaran T, Ravishankar GA, Nedev T, Kosturkova G (2008) Drought induced alterations in growth, osmotic potential and in vitro regeneration of soybean cultivars. Genet Appl Plant Physiol 34:103-112. doi:http://www.bio21. bas.bg/ipp/gapbfiles/v-34 pisa-08/08 pisa 1-2 103-112.pdf

Schittenhelm S, Schroetterm S (2014) Comparison of drought tolerance of, sweet sorghum and sorghum-sudangrass hybrids. J Agron Crop Sci 200:46-53. doi:10.1111/jac.12039

Schlenker W, Roberts MJ (2009) Nonlinear temperature effects indicate severe damages to U.S. crop yields under climate change. PNAS 106:15594-15598. doi:10.1073/pnas.0906865106

Schmidhuber J, Tubiello FN (2007) Global food security under climate change. Proc Natl Acad Sci USA (PNAS) 104(50):19703-19708. doi:10.1073/pnas.0701976104

Scott JK, Murphy H, Kriticos DJ, Webber BL, Ota N, Loechel B (2014) Weeds and climate change: supporting weed management adaptation. CSIRO, Australia

Seneweera S, Milham P, Conroy J (1994) Influence of elevated $\mathrm{CO}_{2}$ and phosphorus nutrition on the growth and yield of a short-duration rice (Oryza sativa L. cv. Jarrah). Aust J Plant Physiol 21:281-292. doi: 10.1071/PP9940281

Sheley RL, Svejcar TJ, Maxwell BD (1996) A theoretical framework for developing successional weed management strategies on rangeland. Weed Technol 10:766-773. ISSN: 0890037X

Song L, Li FM, Fan XW, Xiong YC, Wang WQ, Wu XB, Turner NC (2009) Soil water availability and plant competition affect the yield of spring wheat. Eur J Agron 31:51-60. doi:10.1016/j.eja.2009.03. 003

Song L, Zhang DW, Li FM, Fan XW, Ma Q, Turner NC (2010) Soil water availability alters the inter- and intra-cultivar competition of three spring wheat cultivars bred in different eras. J Agron Crop Sci 196: 323-335. doi:10.1016/j.eja.2009.03.003

Southworth J, Pfeifer RA, Habeck M, Randolph JC, Doering OC, Johnston JJ, Rao DG (2002) Changes in soybean yields in the midwestern United States as a result of future changes in climate, climate variability, and $\mathrm{CO}_{2}$ fertilization. Clim Chang 53(4):447-475. doi:10.1023/A:1015266425630

Starggenborg SA, Dhuyvetter KC, Gordon BW (2008) Grain sorghum and corn comparisons: yield, economic, and environmental responses. Agron J 100:1600-1604. doi:10.2134/agronj2008.0129

Stevanato P, Trebbi D, Bertaggia M, Colombo M, Broccanello C, Concheri G, Saccomani M (2011) Root traits and competitiveness against weeds in sugar beet. Int Sugar J 113:497-501. doi:http:// www.researchgate.net/profile/Piergiorgio Stevanato/publication/ 236848489 Root traits_and_competitiveness against_weeds in 
sugar_beet/links/0deec519e734789524000000.pdf. Accessed 12 Oct 2015

Stone PJ, Nicolas ME (1995) Effect of timing of heat stress during grain filling on two wheat varieties differing in heat tolerance. I. Grain growth. Aust J Plant Physiol 22:927-93. doi:10.1071/PP9950927

Stone MJ, Cralle HT, Chandler JM, Bovey RW, Carson KH (1998) Above- and below-ground interference of wheat (Triticum aestivum) by Italian ryegrass (Lolium multiflorum). Weed Sci 46:438-441. ISSN: 00431745

Storrie A, Cook T (2007) What impact does drought have on weeds? Primefact 430, State of New South Wales through NSW Department of Primary Industries. Job number 7322, pp. 1-3

Stratonovitch P, Storkey J, Semenov AA (2012) A process-based approach to modelling impacts of climate change on the damage niche of an agricultural weed. Glob Chang Biol 18:2071-2080. doi:10. $1111 / j .1365-2486.2012 .02650 . x$

Streck NA (2005) Climate change and agroecosystems: the effect of elevated atmospheric $\mathrm{CO}_{2}$ and temperature on crop growth, development, and yield. Ciencia Rural, Santa Maria 35(3):730-740. doi: http://dx.doi.org/10.1590/S0103-84782005000300041

Taiz L, Zeiger E (1991) Plant physiology. Benjamin/Cummings series. Benjamin-Cummings, Lewiston, p 559

Thomas PEL, Allison JCS (1975) Competition between and Rottboellia exaltata. J Agric Sci 84:305-312

Tian X, Matsui T, Li S, Yoshimoto M, Kobayasi K, Hasegawa T (2010) Heat-induced floret sterility of hybrid rice (Oryza sativa) cultivars under humid and low wind conditions in the field of Jianghan Basin, China. Plant Prod Sci 13(3):243-251. doi:10.1626/pps.13.243

Tokatlidis IS (2013) Adapting maize crop to climate change. Agron Sustain Dev 33:63-79. doi:10.1007/s13593-012-0108-7

Travlos IS (2012) Reduced herbicide rates for an effective weed control in competitive wheat cultivars. Int J Plant Prod 6:1-13. ISSN: 17356814

Trenberth KE, Jones PD, Ambenje P, Bojariu R, Easterling D, Klein Tank A, Parker D, Rahimzadeh F, Renwick JA, Rusticucci M, Soden B, Zhai P (2007) Observations: surface and atmospheric climate change. In: Solomon S, Qin D, Manning M, Chen Z, Marquis M, Averyt KB, Tignor M, Miller HL (eds) Climate change: the physical science basis. Contribution of Working Group I to the Fourth Assessment Report of the Intergovernmental Panel on Climate Change. Cambridge University Press, Cambridge, United Kingdom and New York, NY, USA

Tubiello FN, Ewert F (2002) Simulating the effects of elevated $\mathrm{CO}_{2}$ on crop growth and yield: approaches and applications for climate change. Eur J Agron 18(1-2):57-74. doi:10.1016/S1161-0301(02) 00097-7

Tuong TP, Bouman BAM (2003) Rice production in water-scarce environments. In: Kijne JW, Barker R, Molden D (eds) Water productivity in agriculture: limits and opportunities for improvements. CABI Publishing: 53-67. ISBN: 0851996698, 9780851996691

Ugarte C, Calderini DF, Slafer GA (2007) Grain weight and grain number responsiveness to preanthesis temperature in wheat, barley and triticale. Field Crops Res 100:240-248. doi:10.1016/j.fcr.2006.07.010

Valerio MM, Tomecek B, Lovelli S, Ziska LH (2011) Quantifying the effect of drought on carbon dioxide-induced changes in competition between a $\mathrm{C} 3$ crop (tomato) and a $\mathrm{C} 4$ weed (Amaranthus retroflexus). Weed Res 51:591-600. doi:10.1111/j.1365-3180. 2011.00874.x

Vermeulen SJ, Campbell BM, Ingram JSI (2012) Climate change and food systems. Annu Rev Environ Resour 37:195-222. doi:10. 1146/annurev-environ-020411-130608

Vollmann J, Wagentristl H, Hartl W (2010) The effects of simulated weed pressure on early maturity soybeans. Eur J Agron 32:243-248. doi: 10.1016/j.eja.2010.01.001

Walthall CL, Hatfield J, Backlund P, Lengnick L, Marshall E, Walsh M, Adkins S, Aillery M, Ainsworth EA, Ammann C, Anderson CJ,
Bartomeus I, Baumgard LH, Booker F, Bradley B, Blumenthal DM, Bunce J, Burkey K, Dabney SM, Delgado JA, Dukes J, Funk A, Garrett K, Glenn M, Grantz DA, Goodrich D, Hu S, Izaurralde RC, Jones RAC, Kim SH, Leaky ADB, Lewers K, Mader TL, McClung A, Morgan J, Muth DJ, Nearing M, Oosterhuis DM, Ort D, Parmesan C, Pettigrew WT, Polley W, Rader R, Rice C, Rivington M, Rosskopf E, Salas WA, Sollenberger LE, Srygley R, Stockle C, Takle ES, Timlin D, White JW, Winfree R, WrightMorton L, Ziska LH (2012) Climate change and agriculture in the United States: effects and adaptation. USDA Technical Bulletin 1935. Washington, DC. 186

Waltz E (2014) Beating the heat. Nat Biotechnol 32:610-613. doi:10. $1038 /$ nbt.2948

Wang YP, Jr Handoko, Rimmington GM (1992) Sensitivity of wheat growth to increased air temperature for different scenarios of ambient $\mathrm{CO}_{2}$ concentration and rainfall in Victoria, Australia - a simulation study. Clim Res 2:131-149. doi:10.3354/cr002131

Ward SM, Webster TM, Steckel LE (2013) Palmer amaranth (Amaranthus palmeri): a review. Weed Technol 27:12-27. doi:10. 1614/WT-D-12-00113.1

Wardlaw IF, Moncur L (1995) The response of wheat to high temperature following anthesis. I. The rate and duration of kernel filling. J Plant Physiol 22:391-397. doi:10.1071/PP9950391

Warwick SI, Black LD (1983) The biology of Canadian weeds. 61. Sorghum halepense (L.) Pers. Can J Plant Sci 63:997-1014

Wayne P, Foster S, Connolly J, Bazzaz F, Epstein P (2002) Production of allergenic pollen by ragweed (Ambrosia artemisiifolia L.) is increased in $\mathrm{CO}_{2}$-enriched atmospheres. Ann Allerg Asthma Immunol 8:279-282. doi:10.1016/S1081-1206(10)62009-1

Wheeler TR, Craufurd PQ, Ellis RH, Porter JR, Prasad PVV (2000) Temperature variability and the yield of annual crops. Agric Ecosyst Environ 82:159-167. doi:10.1016/S0167-8809(00)00224-3

Wiese AF, Vandiver CW (1970) Soil moisture effects on competitive ability of weeds. Weed Sci 18:518-519. ISSN: 0043-1745

Winter SR, Musik JT, Porter KB (1988) Evaluation of screening techniques for breeding drought resistant winter wheat. Crop Sci 28: $512-516$

Woodward FI, Williams BG (1987) Climate and plant distribution at global and local scales. Plant Ecol 69(1):189-197. doi:10.1007/ 978-94-009-4061-1_19

Worthington M, Reberg-Horton SC (2013) Breeding cereal crops for enhanced weed suppression: optimizing allelopathy and competitive ability. J Chem Ecol 39:2. doi:10.1007/s10886-013-0247-6

Zhao DL, Atlin GN, Bastiaans L, Spiertz JHJ (2006) Developing selection protocols for weed competitiveness in aerobic rice. Field Crop Res 97:272-285. doi:10.1016/j.fcr.2005.10.008

Zheng S, Nakamoto H, Yoshikawa K, Furuya T, Fukuyama M (2002) Influences of high night temperature on flowering and pod setting in soybean. Plant Prod Sci 5(3):215-218. doi:10.1626/pps.5.215

Zhu C, Zeng Q, Ziska LH, Zhu J, Xie Z, Liu G (2008) Effect of nitrogen supply on carbon dioxide-induced changes in competition between rice and barnyardgrass (Echinochloa crus-galli). Weed Sci 56(1): 66-71. doi:10.1614/WS-07-088.1

Zia-Ul-Haq M, Riaz M, De Feo V (2012) Ipomea hederacea Jacq.: a medicinal herb with promising health benefits. Molecules 17: 13132-13145. doi:10.3390/molecules 171113132

Zimdahl RL (2007) Fundamentals of weed science. Academic, Burlington, p 655

Ziska LH (2003) Evaluation of the growth response of six invasive species to past, present and future carbon dioxide concentrations. J Exp Bot 54:395-404. doi:10.1093/jxb/erg027

Ziska LH (2004) Rising carbon dioxide and weed ecology. In: Inderjit (ed) Weed biology and management. Kluwer Academic, Dordrecht, 159-176. ISBN: 978-90-481-6493-6

Ziska LH (2014) Climate, $\mathrm{CO}_{2}$ and invasive weed management. In: Ziska LH, Dukes JS (eds) Invasive species and global climate change. 
CABI Invasives Series, Boston, Wallingford: 293-305. ISBN: 9781780641645

Ziska LH (2014b) Increasing minimum daily temperatures are associated with enhanced pesticide use in cultivated soybean along a latitudinal gradient in the Mid-Western United States. PLoS ONE 9(6):e98516. doi:10.1371/journal.pone. 0098516

Ziska LH, Bunce JA (2007) Predicting the impact of changing $\mathrm{CO}_{2}$ on crop yields: some thoughts on food. New Phytol 175(4):607-618. doi:10.1111/j.1469-8137.2007.02180.x

Ziska LH, George K (2004) Rising carbon dioxide and invasive, noxious plants: potential threats and consequences. Water Resour Rev 16: 427-446

Ziska LH, Runion GB (2006) Future weed, pest and disease problems for plants. In: Newton P, Carman A, Edwards G, Niklaus P (eds)
Agroecosystems in a changing climate. CRC, New York. Chapter 11: 262-287. ISBN

Ziska LH, Runion GB (2007) Future weed, pest and disease problems for plants. In: Newton PCD, Carran A, Edwards GR, Niklaus PA (eds) Agroecosystems in a changing climate. CRC, Boston, pp 262-279

Ziska LH, Teasdale JR, Bunce JA (1999) Future atmospheric carbon dioxide may increase tolerance to glyphosate. Weed Sci 47:608615. ISSN: 00431745

Ziska LH, Faulkner S, Lydon J (2004) Changes in biomass and root:shoot ratio of field-grown Canada thistle (Cirsium arvense), a noxious, invasive weed, with elevated $\mathrm{CO}_{2}$ : implications for control with glyphosate. Weed Sci 52(4):584-588. doi:10.1614/WS-03-161R 